\title{
The Generalization Effect of Semantic Category- Based Working Memory Treatment on Sentence Comprehension and Word Fluency in Individuals with Aphasia
}

\author{
Hee Jeong Son, Jee Eun Sung \\ Department of Communication Disorders, Graduate School, Ewha Womans University, Seoul, Korea
}

\author{
Correspondence: Jee Eun Sung, PhD \\ Department of Communication Disorders, Ewha \\ Womans University, 52 Ewhayeodae-gil, \\ Seodaemun-gu, Seoul 03760, Korea \\ Tel: $+82-2-3277-2208$ \\ Fax: $+82-2-3277-2122$ \\ E-mail: jeesung@ewha.ac.kr
}

Received: January 5, 2016

Revised: February 9, 2016

Accepted: February 23, 2016

This work was supported by the National Research Foundation of Korea Grant funded by the Korean government (No. NRF-2014S1A5A8018080).

\begin{abstract}
Objectives: The purpose of this study was to examine the generalization effect of semantic category-based working memory (SCWM) treatment on sentence comprehension and word fluency in persons with aphasia. It was predicted that SCWM treatment would enhance working memory capacity and increase sentence comprehension ability and word fluency in patients with aphasia. Methods: Seven Korean individuals with mild to moderate aphasia caused by left hemisphere stroke participated in this study. The interventions were provided in 16 sessions, approximately half an hour per day 2 to 3 times a week. Treatment protocol consisted of an SCWM span task and 4 cues: telling a word list to the participants, showing the participants category cards, showing the participants random word cards, and asking the participants to match category and word cards. A pretest-posttest design was used. Pre-post comparisons were analyzed with the Wilcoxon signed-ranks test. Results: There were significant score increases in the SCWM span task. Furthermore, the SCWM treatment effects were generalized to sentence comprehension ability, categorical word fluency, and working memory span with word forward repetition tasks. Conclusion: The current study suggests that SCWM treatment is effective in enhancing working memory capacity for people with aphasia. Furthermore, the treatment effects were generalized to sentence comprehension ability and categorical word fluency in these patients. The results indicate that working memory is an underlying mechanism associated with sentence comprehension and categorical word fluency and is a critical factor to be considered in language treatment for persons with aphasia.
\end{abstract}

Keywords: Working memory, Semantic category, Sentence comprehension, Word fluency, Aphasia 실어증(aphasia)은 후천적 뇌손상으로 인해 언어습득 후에 생기 는 언어장애로 실어증환자의 언어문제는 영역별 손상 정도의 차이 가 있기는 하지만 특정 언어기능뿐만 아니라 대부분의 이해와 표현 영역 전반에 걸쳐 나타난다(McNeil \& Pratt, 2001). 이러한 실어증환 자들의 언어장애는 언어지식 자체의 손실이라기보다 전반적인 정보 처리과정의 문제로 단기기억 및 작업기억의 결함을 동반한다(Friedmann \& Gvion, 2003; Ko, 2004; McNeil \& Pratt, 2001; Murray, Ballard, \& Karcher, 2004; Vukovic, Vuksanovic, \& Vukovic, 2008). 작업기억(working memory)은 정보를 일시적으로 저장하고 처 리하기 위한 체계이며 이것은 학습, 추론, 읽기이해와 같은 많은 인 지과제에서 작용한다(Baddeley, 1986). 이러한 작업기억 손상은 후 천적 뇌손상 후 나타나는 일반적인 특징으로(Cicerone et al., 2000, 2005; Park \& Ingles, 2001; Robertson \& Murre, 1999; Westerberg et al., 2007), 특히 실어증환자의 작업기억 손상과 언어능력 간의 관 련성에 대한 연구는 최근까지 꾸준히 진행되고 있다. Friedmann과 Gvion (2003)은 작업기억이 매우 제한된 전도성 실어증환자는 음 
운적 거리가 긴, 즉 음운적 재활성화를 요구하는 문장을 이해하는 데 어려움을 보인다고 하였다. 다른 연구자들은 음운, 의미, 통사 등 각 언어영역별 작업기억용량 중 통사 영역의 작업기억 용량이 적을 수록 복잡한 문장구조에 대한 청각적 이해력이 저하된다고 하였고 (Wright, Downey, Gravier, Love, \& Shapiro, 2007), 구문이해와 작 업기억 용량과의 높은 상관관계로 인하여 작업기억 용량을 실어증 환자의 구문이해능력을 예측하는 인자로 사용할 수 있다고 하였다 (Caspari, Parkinson, LaPointe, \& Katz, 1998). 또한 Sung 등(2009) 은 실어증환자의 구어작업기억이 문장읽기 및 이해에 영향을 미친 다고 하였다. Cho와 Kim (2002)은 실어증환자의 작업기억 용량에 따른 문장이해의 차이가 실어증 유형과의 관련성보다도 더 많은 상 관이 있다고 하였다. 실어증환자를 대상으로 한 단기기억 및 작업 기억과 문장처리의 상관에 대한 연구에서 실어증환자들은 숫자 바 로 및 거꾸로 따라지시하기, 단어 바로 및 거꾸로 따라지시하기 모 두에서 정상인들에 비해 낮은 수행력을 보였으며, 특히 단기기억을 나타내는 바로 따라지시하기 과제는 문장처리과정을 평가한 Computerized Revised Token Test-Auditory (McNeil et al., 2008)와 유 의한 상관관계를 보였다고 하였다(Sung, 2010). Kim, Sung과 Kim (2013)은 작업기억 능력이 실어증환자의 문장이해능력에 미치는 영향에 대한 연구에서 정상과 실어증환자 모두 작업기억 능력과 문장이해능력 간의 상관관계가 높은 것으로 나타났다고 하였다. 또한 실어증환자의 제한된 구어표현이 대부분 유창성, 특히 스스 로 말하기, 이름대기에서 나타나는 것은 주로 전두엽의 손상으로 인한 기능저하로 해석된다(Janowsky, Shimamura, Kritchevsky, \& Squire, 1989). 이전 연구들에서 실어증환자들은 비실어증 뇌손상 환자들보다 단어유창성 능력이 떨어진다고 보고하였다(Goodglass \& Kaplan, 1983; Grossman, 1981). Dunn, Russell과 Drummond (1989)의 연구에서는 범주유창성 과제에서의 정상, 유창성실어증, 비유창성실어증 집단 간 평균 산출어휘가 유의미한 양적 차이를 보였다. 실어증환자를 포함한 91명의 뇌손상자 집단을 대상으로 음 소유창성 능력을 살펴본 Bruyer와 Tuyumbu (1980)의 연구에서는 실어증환자와 전두엽 손상 환자 모두가 산출한 단어 수와 정반응 한 단어 수가 정상집단보다 적었으며 오반응한 수와 유형에서도 차 이가 있다고 하였다. 다른 연구에서는 서로 다른 중증도의 실어증 환자군에게 범주 및 음소유창성 과제를 실시하였을 때, 제시되는 단서에 따라 반응 전략뿐 아니라 전략을 사용하는 빈도에도 서로 차이가 있음을 발견하였다(Coehlo, Kimbarow, \& Boyle, 1987). Baldo, Ludy, Wilkins와 Dronkers (2002)는 중도(severe) 베르니케 실어증환자 두 명을 대상으로 범주 및 음소유창성 과제의 수행력 을 비교하는 연구에서 범주유창성 과제보다 음소유창성 과제에서
더 높은 수행을 보였으며, 이를 음소유창성 과제는 의미체계에 접 근하지 않은 채 이루어지기 때문이라고 해석하였다. 이러한 결과를 종합하여 볼 때 실어증환자는 단어유창성에 있어서 양적, 질적인 면 모두에서 제한되어있다는 것을 알 수 있다(Adams, Reich, \& Flowers, 1989). 즉, 실어증환자는 정상집단에 비하여 단어유창성 과제 시 산출한 어휘 수도 적지만, 산출한 어휘의 전형성과 단어를 효율 적으로 연상하기 위한 반응전략도 떨어진다는 것을 알 수 있다.

실어증환자의 경우 회복된 후에도 여전히 존재하는 작업기억 결 함으로 인하여 대화유지와 복잡한 문장 또는 장문의 글을 이해하 는 데 어려움이 있으며 여러 사람과 대화를 하거나 동시에 두 가지 일을 하는 것에도 어려움이 있다고 보고되고 있다. 이는 종종 실어 증환자의 사회적 기능과 직업적 수행에 있어서 심각한 문제를 야기 시킨다. 작업기억이 요구되는 과제에서 작업기억 손상의 정도는 뇌 졸중 회복을 예측하는 결정적인 요소이며(Robertson \& Murre, 1999), 사회로 복귀할 수 있는 가능성을 예측하는 요소가 될 수 있 다(Brooks, 1987; Van Zomeren \& Van Den Burg, 1985). 작업기억 용량과 주의력은 기본적인 인지능력을 넘어서 다른 기능들의 재활 에까지 영향을 미치며(Malouin, Belleville, Richards, Desrosiers, \& Doyon, 2004), 이러한 작업기억의 손상은 실어증환자의 중요한 치 료적 접근이 된다.

일반적으로 작업기억 중재는 전반적인 작업기억 용량(capacity) 을 늘리거나 작업기억을 전략적으로 사용하는 두 가지로 크게 나 눌 수 있다(Turley-Ames \& Whitfield, 2003). 전자의 경우, 요구되 는 작업기억이 사용 가능한 한도에 대한 개인차가 있으며 이러한 작업기억의 용량이 적은 사람은 작업기억의 요구가 증가함에 따라 수행력이 감소할 것이라고 가정한다(Jaeggi, Buschkuehl, Jonides, \& Perrig, 2008). 반면 후자의 경우, 작업기억 폭(span)의 높고 낮음 은 작업기억 과제에서 할당된 작업기억을 불필요한 정보를 억제하 는데 얼마나 효율적인 전략을 사용하는지가 결정한다고 가정한다. 실제로 Kane과 Engle (2000)은 작업기억이 높은 사람은 낮은 사람 보다 필요 없는 정보의 간섭을 제어하고 정보를 회상하기 위한 전 략을 더 많이 사용한다고 하였다. 이에 따라 작업기억 중재의 유형 을 핵심훈련(core training)과 전략훈련(strategy training)으로 구 분할 수 있다(Morrison \& Chein, 2011). 핵심훈련은 동시 과제의 간 섭에도 불구하고 정보를 기억해야 하는 부담이 큰 경쟁과제를 반복 하게 하는 것이며, 반면 전략훈련은 특정 기억전략(memory strategy) 및 시.청각자극을 사용하여 많은 양의 정보를 기억하게 하는 것이다. 여기서 기억전략이란 기억수행을 향상시키기 위해 사용하 는 계획적이고 목표지향적인 의식적 행동으로(Hasher \& Zacks, 1979; Naus, 1974), 크게 시연(rehearsal), 정교화(elaboration), 조직 
화(organization)가 있다(Lee, 1992).

실어증환자들을 대상으로 작업기억 중재의 효과성을 확인하고 자 많은 연구가 진행되어왔다(Eom, 2015; Francis, Clark, \& Humphreys, 2003; Kalinyak-Fliszar, Kohen, \& Martin, 2011; Martin, Kohen, McCluskey, Kalinyak-Fliszar, \& Gruberg, 2009; Salis, 2012; Vallat et al., 2005; Winans et al., 2012). Salis (2012)는 중도(severe) 의 실어증환자 1 명을 대상으로 듣기폭 과제를 포함한 단기기억훈련 을 한 결과, 단기기억뿐 아니라 문장이해에까지 일반화 효과가 나타 났다고 하였다. 단어폭 과제와 익숙한 문단(text)수준의 읽기과제 를 사용하여 경도 실어증과 읽기장애를 보이는 피험자의 이해 향 상을 살펴본 Mayer와 Murray (2002)의 연구에서는 두 과제 모두 읽기속도에는 향상을 보였지만 읽기이해에는 향상을 보이지 않았 다. 또한 중도의 실어증환자를 대상으로 듣기폭 과제에 기초한 작업 기억 중재의 효과성을 살펴본 결과, 듣기폭과 문장이해력에서는 유 의한 향상을 보였지만 유지 및 다른 작업기억 과제에 대한 일반화 는 나타나지 않았다(Winans et al., 2012). Vallat 등(2005)은 구어작 업기억의 특정 손상을 가진 실어증환자에게 작업기억 중재를 하였 을 때, 구어작업기억과 중앙집행기능에 유의한 향상을 보였으나 읽 기이해에는 유의미하지 않았다. 경도 실어증환자와 이해에 어려움 을 보이는 환자에게 문장 따라말하기 과제를 실시한 연구에서는 청 각적 기억과제에서는 향상을 보였으나 이해에서는 제한된 향상을 보였다(Francis et al., 2003). 또 다른 연구에서는 자극과 반응 사이 의 지연간격에 따른 문장 따라말하기 과제를 사용하였는데(Kalinyak-Fliszar et al., 2011; Martin et al., 2009), 연구에 참여한 베르니 케 및 전도성 실어증환자들의 따라말하기와 기억폭 과제, 표준화된 이해과제에서 향상을 보였다. 국내에서는 Eom (2015)의 연구에서 실어증환자 6명을 대상으로 문장 따라말하기를 활용한 작업기억 중재를 실시하여 문장이해능력에 미치는 효과를 알아보았다. 그 결 과, 중재 및 비중재 문장 따라말하기에 향상을 보였으며 숫자 및 단 어폭 과제뿐 아니라 문장이해, 전반적인 의사소통 능력에도 유의한 향상을 나타내었다. 그러나 기존의 실어증환자를 대상으로 한작업 기억 중재는 대부분 핵심훈련, 즉 작업기억의 저장과 처리를 사용 하는 특정 과제(따라말하기, 듣기폭 과제 등)를 반복하는 중재기법 을 대부분 적용하였고, 중재효과에 있어서도 비일관적인 결과를 보 인다. 대상자 또한 한 명의 피험자인 파일럿 연구 형태이거나 전도 성 실어증환자군에 한정되어있어 실어증환자 전반에 그 결과를 일 반화하기에는 무리가 있다. 그뿐만 아니라작업기억 중재로 인한작 업기억의 향상이 문장이해나 단어유창성 등의 언어영역으로 일반 화 효과가 나타나는지에 대한 연구도 매우 제한적인 실정이다.

따라서 본 연구에서는 과제 반복을 통해 작업기억의 용량(capac- ity)을 확장하고, 작업기억을 효율적으로 사용하는 기억전략과 시 청각적 자극을 활용할 수 있도록 중재를 고안하였다. 더불어 이러 한 작업기억 중재를 다양한 유형의 실어증환자에게 적용하여 작업 기억 능력의 향상이 문장이해 및 단어유창성에 미치는 일반화 효 과를 알아보고자 한다.

본 연구의 구체적인 질문은 아래와 같다.

첫째, 작업기억 중재 전후에 따라 실어증환자의 중재 작업기억 과제 수행력에 유의한 차이가 있는가?

둘째, 작업기억 중재 전후에 따라 실어증환자의 비중재 작업기억 과제 수행력에 일반화 효과가 유의한가?

셋째, 작업기억 중재 전후에 따라 실어증환자의 문장이해과제 정 확도에 일반화 효과가 유의한가?

넷째, 작업기억 중재 전후에 따라 실어증환자의 단어유창성 과 제 수행력에 일반화 효과가 유의한가?

\section{연구 방법}

\section{연구대상}

본 연구의 대상은 서울 및 경기도 소재의 재활병원 입원 또는 외 래환자 중에서 한국어를 모국어로 사용하는 실어증환자 7명을 대 상으로 하였다. 실어증환자는 뇌졸중 발병 후 6 개월까지는 언어뿐 만 아니라 신체적, 정서적 및 일상생활활동에서 전반적인 회복을 보이지만 6개월 이상 경과 시, 큰 변화를 보이지 않는다(Duncan, Goldstein, Matchar, Drivine, \& Feussner, 1992; Lendrem \& Lincoln, 1985). 따라서 자연회복(spontaneous recovery)으로 인하여 초기 기능 회복 기간이 지난 대상자, 연구의 목적을 이해하며 훈련 효과에 영향을 줄 수 있는 요인이 최소한인 대상자로 선정하였다 (Swan, Otani, Loubert, Sheffert, \& Dunbar, 2004; Weiss et al., 1994).

구체적인 선정기준은 (1) 좌뇌의 피질 및 피질하 부위의 뇌졸중에 기인한 언어장애를 보이는 자, (2) 한국판 웨스턴 실어증 검사(Kim $\& \mathrm{Na}, 2001)$ 결과, 실어증으로 분류된 자, (3) 발병 전 주 손잡이가 오 른손이었던 자, (4) 발병 이전에 뇌손상 및 기타 신경학적 질환이 없 었다고 보고된 자, (5) 검사지침 및 중재에 대한 이해와 구어적 반응 이 가능하여야 하므로 한국판 웨스턴 실어증 검사 $(\mathrm{Kim} \& \mathrm{Na}, 2001)$ 에서 경도(mild)에서 중등도(moderate)에 해당하는 자, (6) 최종 발 병 후 6개월 이상 경과한 자, (7) 연령과 교육수준 차이가 수행에 미 치는 영향을 최소화하기 위하여 75세 이하이며, 초등학교 졸업 이 상의 학력을 갖춘 자를 대상으로 하였다(Kang, Chin, Na, Lee, \& Park, 2000). 이를 바탕으로 연구 참여자들의 개인별 특성은 Table 1 에, 사전·사후평가의 수행도는 Appendix 1에 제시하였다. 
Table 1. Demographic information on participants with aphasia

\begin{tabular}{|c|c|c|c|c|c|c|c|}
\hline & \multicolumn{7}{|c|}{ Participant ID } \\
\hline & 1 & 2 & 3 & 4 & 5 & 6 & 7 \\
\hline Gender & $M$ & $M$ & $M$ & M & M & $M$ & $M$ \\
\hline Age (yr) & 59 & 49 & 21 & 34 & 54 & 26 & 46 \\
\hline Education (yr) & 7 & 16 & 14 & 12 & 16 & 12 & 12 \\
\hline Post onset (mo) & 6 & 50 & 24 & 15 & 34 & 9 & 6 \\
\hline Lesion & Lt. MCA & Lt. MCA & Lt. MCA & $\begin{array}{c}\text { T-ICH } \\
\text { Lt. FH contusion }\end{array}$ & Lt. MCA & Lt. BG ICH & Lt. ICH \\
\hline \multicolumn{8}{|l|}{ K-WAB } \\
\hline $\mathrm{AO}$ & 81 & 73.5 & 94.3 & 87.6 & 63.4 & 61.4 & 64.9 \\
\hline Fluency & 5 & 5 & 9 & 9 & 5 & 4 & 7 \\
\hline Auditory verbal comprehension & 9.7 & 8.35 & 9.85 & 8.6 & 5.1 & 7.7 & 7.45 \\
\hline Repetition & 9.0 & 6.8 & 8.6 & 7.4 & 9.8 & 6.5 & 3.0 \\
\hline Naming & 8.8 & 5.5 & 9.7 & 8.8 & 5.8 & 7.0 & 7.0 \\
\hline Type of aphasia & Anomic & Conduction & Anomic & Anomic & Transcortical sensory & Conduction & Conduction \\
\hline
\end{tabular}

$\mathrm{MCA}=$ middle cerebral artery; $\mathrm{T}-\mathrm{ICH}=$ traumatic-intracerebral hemorrhage; $\mathrm{FH}$ contusion=frontal hemorrhagic contusion; $\mathrm{BG}=$ basal ganglia; $I \mathrm{CH}=$ intracerebral hemorrhage; $\mathrm{K}-\mathrm{WAB}=$ Korean-Western Aphasia Battery (Kim \& Na, 2001); $\mathrm{AQ}=$ aphasia quitient.

\section{사전-사후평가}

\section{중재 작업기억 과제}

중재 작업기억 과제는 De Beni, Palladino와 Pazzaglia (1998)의 연구에서 사용된 작업기억 과제를 국내실정에 맞게 수정하고, 그 를 바탕으로 중재 작업기억 과제를 새롭게 고안하였다. 본 연구에 서는 목표범주를 두 가지(동물, 교통기관)로 설정하였고, 기존의 과 제에서 난이도를 방해단어의 개수를 조절한 것과 달리 단어목록 의 개수를 추가하여 회상할 단어폭(span)을 늘림으로써 난이도를 조절하였다. 이를 의미범주 작업기억 과제(Semantic Category Working Memory Span Task)라고 지칭하며, 중재 전후 작업기억 평가 과 제로 사용하였다. 이는 일련의 단어목록을 들으며 목표범주(동물, 교통기관)의 단어가 나오면 책상을 치고, 각 단어목록의 마지막 단 어를 회상해야 하는 과제이다. 이는 문장의 이해가 요구되지는 않 으나 의미적 단서에 의해 활성화된 정보를 처리하고 회상하는 일련 의 과정을 거치게 된다. 구체적인 실시지침 및 채점기준은 Appen$\operatorname{dix} 2$ 에 제시하였다.

\section{비중재 작업기억 과제}

비중재 작업기억 과제로는 한국판 웩슬러 성인용 지능검사 4판 (Korean-Wechsler Adult Intelligence Scale-IV, K-WAIS-IV; Hwang et al., trans, 2012)의 숫자 바로 및 거꾸로 따라말하기 과제와 Sung (2011)의 단어 바로 및 거꾸로 따라말하기 과제를 실시하였다. 점수 는 각 과제의 작업기억폭(span)을 사용하였다.

\section{문장이해과제}

문장이해를 살펴보기 위한 과제로 Hyun, Sung, Jeong, Kang과 $\operatorname{Kim}$ (2013)의 통사적 복잡성에 따른 격조사처리과제를 수정·보완 한 문장이해과제(Sung, 2015)를 실시하였다. 이는 의미적 요소가 통제된 한국어 문장의 규범·비규범 어순 및 능동·피동관계에 따 른 문장이해를 평가하는 과제로 문장을 듣고 제시되는 두 가지 그 림 중 목표문장과 일치하는 그림을 선택하는 과제이다. 문장은 세 가지 통사구조(능동문-2항동사, 피동문, 능동문-3항동사)와 각 통 사구조별로 규범 및 비규범 어순으로 분류하여 총 6가지 유형이며, 각 유형별로 6 개의 문항으로 이루어져 총 36 개의 문항으로 구성하 였다. 점수는 한 문항당 1점으로 총점 36점을 기준으로 정확도(\%) 를 산출하여 계산하였다.

\section{단어유창성}

단어유창성 과제는 Kang 등(2000)에서 사용된 통제단어연상 과 제(Controlled Oral Word Association Test, COWAT)를 실시하였 다. COWAT는 범주유창성 과제와 음소유창성 과제의 2가지 종류 가 있다. 이 과제들은 특정 범주(예: 동물, 가게물건)에 속하는 단어 들이나 특정 음소(예: ㄱ, ㅅ, ㅇ)로 시작하는 단어들을 제한된 시 간(1분) 내에 자발적으로 얼마나 많이 말할 수 있는지를 측정하는 생성이름대기 검사이다(Kang et al., 2000). 점수는 대상자가 1 분간 나열한 단어의 수를 사용하였으며, 범주유창성 과제의 경우는 각 범주에서 산출된 모든 단어의 합계, 음소유창성 과제의 경우는 세 가지 음소에서 산출된 모든 단어의 합계를 점수로 사용하였다. 해 당 범주에 속하는 단어를 정확히 산출하였을 경우만 정답으로 하 
였고, 반복하거나 불명료한 단어, 해당 범주와 무관한 단어는 0 점 으로 처리하였다.

\section{의미범주기반 작업기억 중재}

작업기억 중재는 의미범주 작업기억 과제를 반복하는 동안 마지 막 단어 회상에 오반응 하면 의미범주화를 통한 기억전략과 시·청 각적 자극을 활용할수 있도록 순차적으로 단서를 제시하는 중재 프 로토콜이다. 여기서 단서는 Montgomery (2000a, 2000b)와 Conners, Rosenquist, Arnett, Moore와 Hume (2008)의 연구를 참고하여 단 어목록을 끊어서 들려주기, 범주카드 제시하기, 단어카드 무선적으 로 제시하기, 범주 및 단어카드 매칭하기 등 4 가지로 구성하였다. 본 연구에서는 이를 의미범주기반 작업기억 중재(Semantic Categorybased Working Memory Treatment)라고 지칭하였다.

\section{중재 자극}

의미범주 작업기억 과제에서 단어(word)는 기존 연구(Ahn, 2010; Kim \& Kang, 2005; Lee, 2003; Rhee, 1991; Shin, 2003)를 참고하여 기능적인 범주를 우선적으로 선정하였다. 목표범주의 단어는 생물 범주(동물)와무생물범주(교통수단)에서 각각 10 개의 단어를 선정 하였고, 비목표범주의 단어는 생물범주(과채류)와 무생물범주(생 활용품)에서 각각 20 개씩 총 40 개의 단어를 선정하였다. 단어는 각 범주의 전형적 고빈도 어휘 중 2-3음절 단어로 구성하였고, 각 단어 의 받침 수나 받침의 위치, 음절 수는 최대한 일정하게 통일된 출현 빈도로 구성하였다. 이는 한국어 어휘특성들이 기억폭에 미치는 효과를 최소화하기 위한 것이다(Park, Park, \& Kim, 2006). 단어목 록(word list)은 3개의 단어로 구성하였고, 두 가지 목표범주(동물, 교통기관) 단어 각각 1 개와 비목표범주(생물1, 무생물1) 단어 1 개를 무선적으로 추출하여 다양한 위치에 배열하였다. 단어폭(span)은 한 세트(set)를 구성하는 단어목록의 수를 하나씩 추가하여 늘려 갔다. 예를 들어 단어폭 2 는 단어목록 2 개 구성이 한 세트가 되며, 단어폭 3 은 단어목록 3 개 구성이 한 세트가 된다. 최소 단어폭 2 에 서 최대 단어폭 5 까지 있으며, 각 단어폭당 총 12 개의 세트로 구성 하였다. 한 세트에서는 같은 단어가 반복되지 않고 각 단어폭의 단 어목록에는 같은 단어가 6회 이상 반복되지 않는 것을 원칙으로 하 였다. 이와 같은 방법으로 구성된 중재 단어목록을 두 가지 버전으 로 준비하여 매 회기마다 무선적으로 제시하였으며 대상자의 수행 정도에 따라 두 가지 버전의 단어목록을 번갈아 가며 제시하였다. 자세한 단어목록 구성 예시는 Figure 1에 제시하였으며, 중재 단어 목록은 Appendix 3에 제시하였다.

\section{중재 프로토콜}

단어폭 설정

중재를 시작하는 단어폭은 대상자의 사전검사 시 의미범주 작업 기억 과제의 “단어폭(span)-1"에 해당하는 단어폭에서 시작한다. 예를 들어, 단어폭 3 인 경우 단어폭 2 부터 시작하고 단어폭 2 인 경 우에는 최소 단어폭인 단어폭 2 부터 시작한다. 단, 단어폭 3.5 인 경 우 부분점수 0.5 를 버린 단어폭 2 에서 시작한다. 2 회기부터는 "이 전 회기에서 대상자가 단서 없이 $80 \%$ 이상 정반응 한 단어폭-1”에 해당하는 단어폭에서 중재를 시작한다.

중재는 연구자가 대상자의 맞은편에 앉아서 진행되었으며, 중재

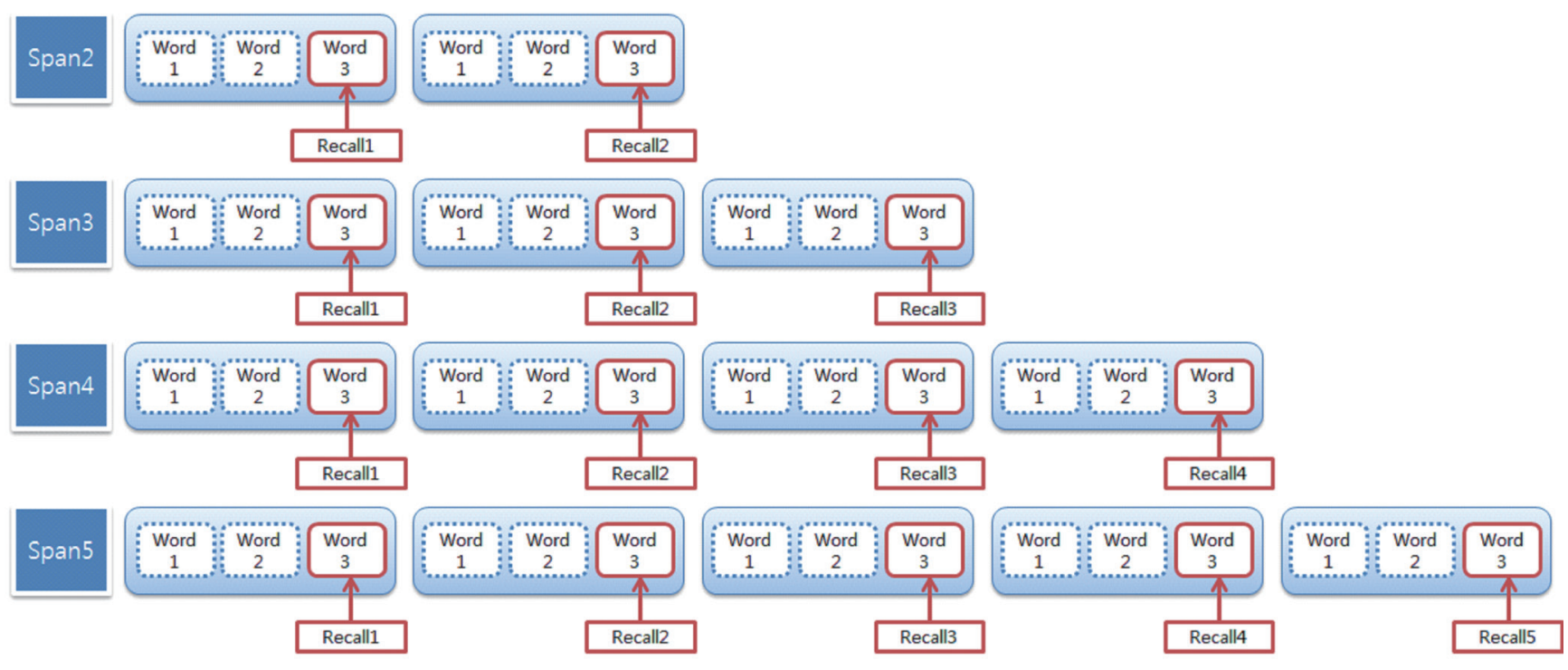

Figure 1. Examples of word list composition. 
에 대한 설명과 연습을 충분히 한 후 시작하였다. 단어목록을 청각 적으로 제시할 때, 단어 간 간격은 1 초, 단어목록(word list) 간 간격 은 2초로 제시하였다. 만약 외부 소음 등에 의해 대상자가 듣지 못 하여 반복청취를 요구하면 1 회까지 다시 들려주었다.

연구자는 대상자에게 “자, 지금부터 3개의 단어로 이루어진 단 어목록 2 개, 즉 단어 여섯 개를 듣게 됩니다. 여섯 개의 단어 중 $\bigcirc$ $\bigcirc$ (목표범주, 예: 동물)에 해당하는 단어가 나오면 즉시 책상을 치 시고, 각 단어목록의 마지막 단어, 다시 말해 여섯 개의 단어 중 세 번째, 여섯 번째 단어를 기억해서 저에게 말해주세요.”라고 말하고, 단어목록을 적당한 크기로 들려주었다. 대상자는 "사과-버스-기린 /토끼-휴지-지하철”이라는 단어목록을 듣고 '기린', ‘토끼' 다음에 즉시 손바닥으로 책상을 치고, 한 세트의 단어목록을 다 들은 후에 '기린, 지하철'을 회상하였다. 중재에 대한 구체적인 예시는 Figure 2 에 제시하였다.

\section{오반응시단서 제시}

대상자가 해당 단어폭의 각 세트에서 단어를 회상하지 못하거나 오반응 할 경우, 기억전략 및 시청각적 자극을 활용할 수 있도록 순 차적으로 단서를 제시하였다.

단서 1. 끊어서 들려주기: 대상자가 해당 단어폭의 각 세트에서 단어를 회상하지 못할 경우, 첫 번째 단서로 각 세트의 단어목록을 하나씩 끊어서 들려주고 마지막 단어를 회상하도록 한다. 첫 번째 단서에서 정반응 하면, 이전 세트를 재시도하고 여기서 다시 정반 응 하면 다음 세트로 넘어간다. 첫 번째 단서에서 오반응 하거나 첫 번째 단서에는 정반응 하였으나 이전 세트 재시도 시 다시 오반응 하면 두 번째 단서를 제시한다.

단서 2. 범주카드 제시: 첫 번째 단서에서 오반응 하거나 첫 번 째 단서에 정반응 하였으나 이전 세트 재시도 시 다시 오반응 할 경 우, 두 번째 단서를 제시한다. 두 번째 단서는 대상자에게 단어목록 을 하나씩 끊어서 들려주고, 치료사가 제시하는 각 단어에 해당하

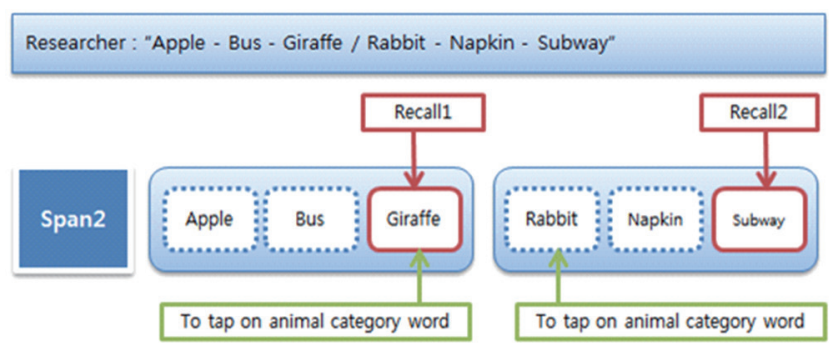

Subject : "Giraffe, Subway"

Figure 2. Example of semantic categorical working memory task.
는 범주카드를 보며 마지막 단어를 회상하도록 한다. 범주카드의 예시는 Figure 3과 같이 갤럭시탭 프로 8.4 (8.4인치 LCD $2560 \times$ $1600,2.3 \mathrm{GHz}$ 쿼드코어, RAM $2 \mathrm{~GB}$ ) 화면에 글자크기 30 point로 제시하였다. 두 번째 단서에서 정반응 하면 이전 세트를 재시도하고 여기서 다시 정반응 하면 다음 세트로 넘어가고, 그렇지 않으면 세 번째 단서를 제시한다.

단서 3. 단어카드 무선적 제시: 두 번째 단서에서 오반응 하거 나 두 번째 단서에는 정반응 하였으나 이전 세트 재시도 시 다시 오 반응 할 경우, 세 번째 단서를 제시한다. 세 번째 단서는 대상자에게 단어목록을 하나씩 끊어서 들려주고 각 단어에 해당하는 범주카 드와 함께 무선적으로 제시된 단어카드를 보며 마지막 단어를 회 상하도록 한다. 범주 및 단어카드의 예시는 Figure 4 와 같이 단서 2 와 동일한 태블릿 PC화면에 글자크기 30 point로 제시하였다. 세 번째 단서에서 정반응 하면 이전 세트를 재시도하고 여기서 다시 정

$\mathrm{Tx}_{\mathrm{x}}>$ Span2-1Set $>$ Cue2

Word list $1 / 2$

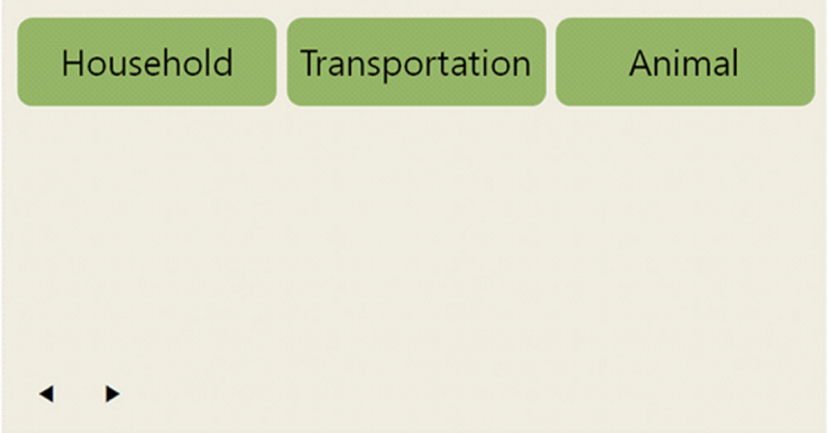

Figure 3. Cue2: presentation of semantic category cards.

Tx. > Span2-1Set $>$ Cue3

Word list $1 / 2$

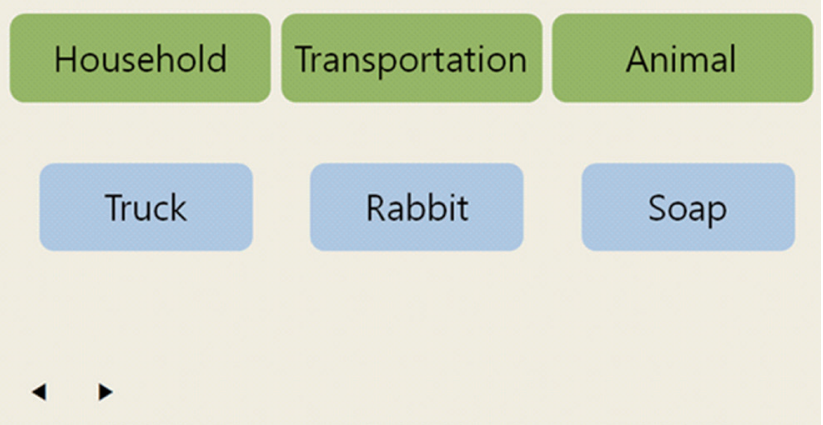

Figure 4. Cue3: presentation of semantic items for each category. 
반응 하면 다음 세트로 넘어가고, 그렇지 않으면 네 번째 단서를 제 시한다.

단서 4. 범주 및 단어카드 매칭: 세 번째 단서에서 오반응 하거나 세 번째 단서에는 정반응 하였으나이전 세트 재시도 시 다시 오반응 할 경우, 네 번째 단서를 제시한다. 네 번째 단서는 대상자에게 단어 목록을 하나씩 끊어서 들려주고 각 단어에 해당하는 범주카드와무 선적으로 제시된 단어카드를 매칭한 후, 매칭한 단어목록을 보고 마 지막 단어를 회상하도록 한다. 범주 및 단어카드의 예시는 Figure 5 와 같이 이전의 단서와 동일한 태블릿 PC화면에 글자크기 30 point 로 제시하였고, 대상자가 직접 손으로 드래그하여 매칭한다. 네 번째 단서에서 정반응 하면 이전 세트를 재시도 하고 여기서는 정오에 상 관없이 다음 세트로 넘어간다. 단, 네 번째 단서에서도 오반응 하면 바로 다음 세트로 넘어간다.

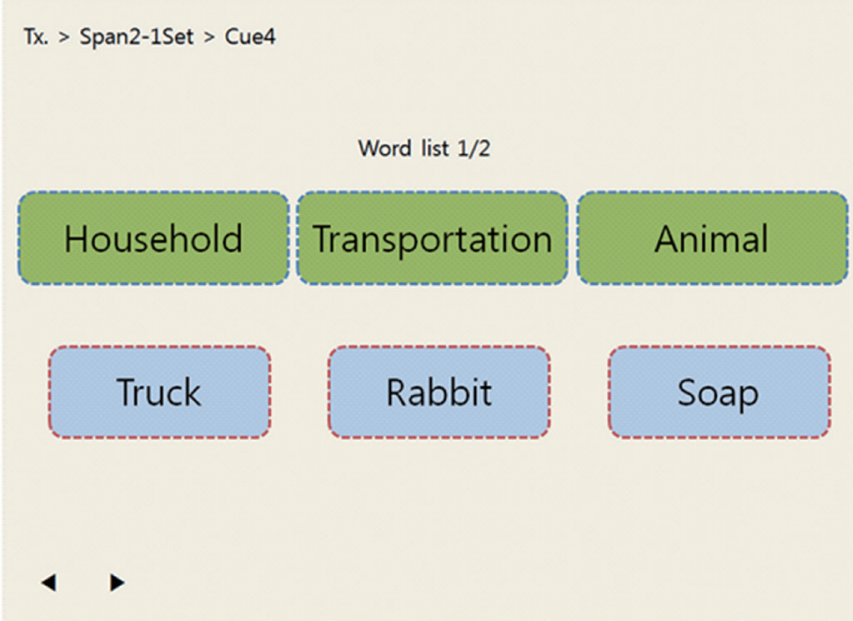

각 단어폭에서 총 12 세트 중, 단서 없이 $80 \%$ 이상(10세트) 정반 응 하면 다음 단어폭(현재 단어폭+1)으로 진행하고, 그렇지 않으면 같은 단어폭에서 두 번째 버전의 단어목록으로 실시한다. 세트의 진행 및 단서 제시 절차의 예시는 Figure 6에 요약하였고, 단어폭 진 행 절차의 예시는 Table 2 와같다.

\section{실험설계 및 통계분석}

본 연구는 사전·사후 비교 설계(pretest-posttest design)를 사용 하였으며, (1) 사전평가, (2) 중재, (3) 사후평가 단계로 구성되었다. 사전평가 단계에서는 대상자 적합성 판단 및 기초자료 수집과 실험 에 대한 동의 및 설명을 한 다음에 사전평가를 실시하였다. 중재는 재활병원 내 언어치료실에서 연구자와 대상자가 일대일로 진행하 였다. 중재 기간은 사전-사후 평가를 포함하여 총 16 회기로, 주 2-3

Figure 5. Cue4: presentation of semantic category-item mapping.

\section{$\mathrm{TX}$. > Span2-1Set > Cue4}

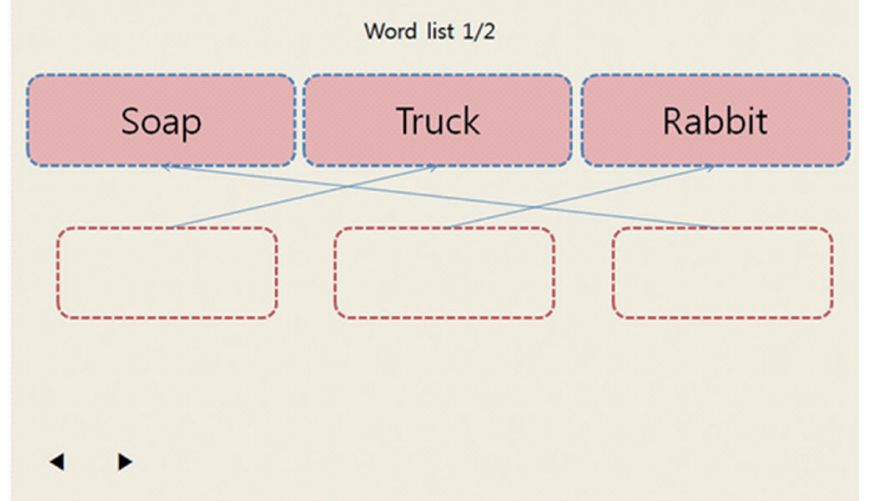

\section{Span 2}

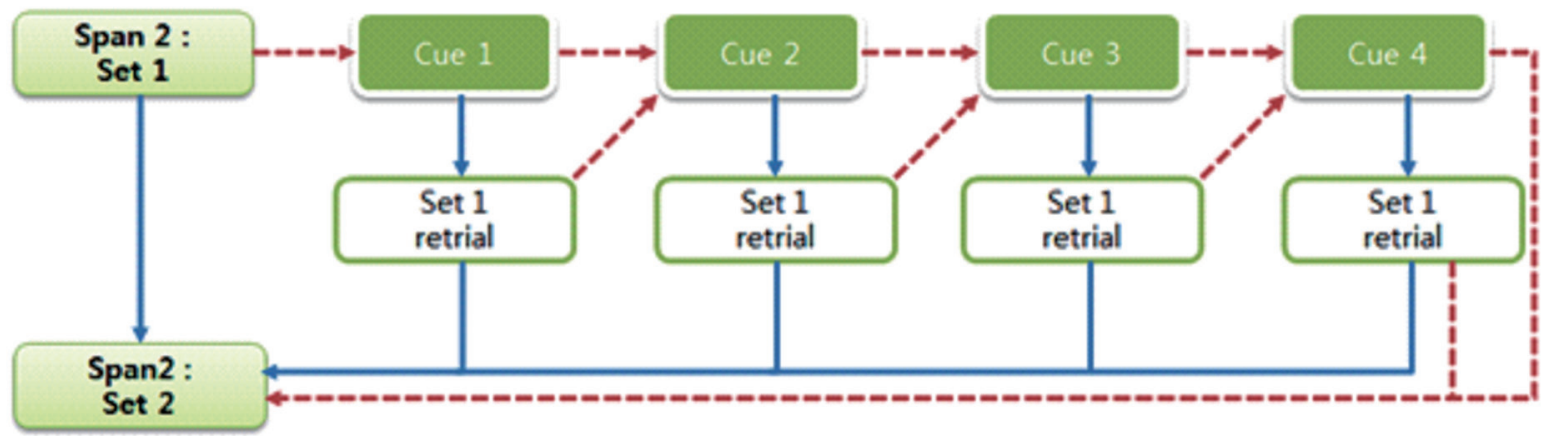

Figure 6. Hierarchy of cue presentations. 
Table 2. Example of treatment protocol process

\begin{tabular}{lll}
\hline Span & No. of correct responses without cue (total 12 set) & Process \\
\hline 2 & $\geq 10 \mathrm{set}$ & Span3 \\
& $<10 \mathrm{set}$ & Span2 retrial \\
3 & $\geq 10 \mathrm{set}$ & Span4 \\
& $<10 \mathrm{set}$ & Span3 retrial \\
& $\geq 10 \mathrm{set}$ & Span5 \\
4 & $<10 \mathrm{set}$ & Span4 retrial \\
& $\geq 10 \mathrm{set}$ & End of Tx. \\
5 & $<10 \mathrm{set}$ & Span5 retrial \\
\hline
\end{tabular}

회씩 총 6-8주 동안 진행하였다. 한 회기는 대상자의 피로도를 고려 하여 약 30 분으로 하되 대상자의 수행 정도에 따라 가감하였다. 중 재단계에서는 본 연구의 종속변인에 영향을 줄 수 있는 다른 인지 및 언어치료에 참여하지 못하도록 하였다. 사후평가는 중재가 종료 된 다음 날부터 중재효과 검증 자료를 수집하였다. 사전·사후평가 는 환자 수행에 따라 1-2회기에 걸쳐 진행되었고, 동일한 절차와 과 제로 진행되었다.

통계분석은 실어증환자의 의미범주기반 작업기억 중재 후, 사전. 사후의 작업기억, 문장이해 및 단어유창성으로의 일반화 효과가 있는지를 검증하기 위해 비모수적인 통계 방법인 윌콕슨 부호순위 검정(Wilcoxon signed-rank test)을 실시하였다.

\section{연구 결과}

\section{의미범주 작업기억 과제 중재효과}

작업기억 중재 실시 전후에 의미범주 작업기억 과제 단어폭의 차 이가 유의미한지를 알아보기 위해 두 가지 범주(동물, 교통기관) 작 업기억 과제 단어폭의 평균을 분석하였다. 그 결과, 중재 후 단어폭 이 유의하게 증가한 것으로 나타났다 $(Z=-2.388, p<.05)$. 즉 Figure 7 과 같이 중재 전 의미범주 작업기억 과제의 단어폭이 1.61 에서 중 재 후에는 2.39 로 증가하였다.

\section{비중재 작업기억 과제로의 일반화 효과}

숫자 바로 및 거꾸로 따라말하기 과제 점수 전후 비교

숫자 바로 따라말하기

작업기억 중재 실시 전후에 숫자 바로 따라말하기 과제 숫자폭 의 차이가 유의미한지를 알아보기 위해 분석한 결과, 중재 후 숫자 폭이 유의하게 증가하지 않았다 $(Z=-1.000, p>.05)$. 즉 Figure 8과 같이 중재 전 숫자 바로 따라말하기 숫자폭이 4.43 에서 중재 후에 는 4.71로 증가하였지만 유의하지 않았다.

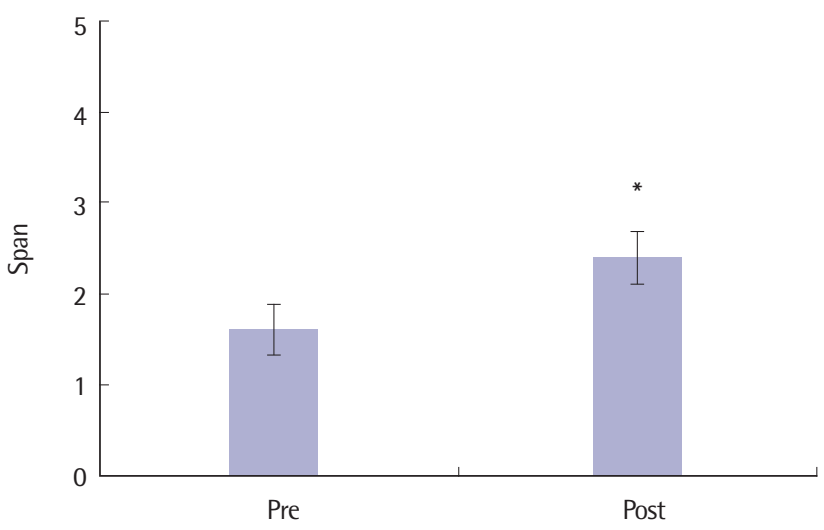

Figure 7. Pre-post comparison of semantic categorical working memory span task. ${ }^{*} p<.05$.

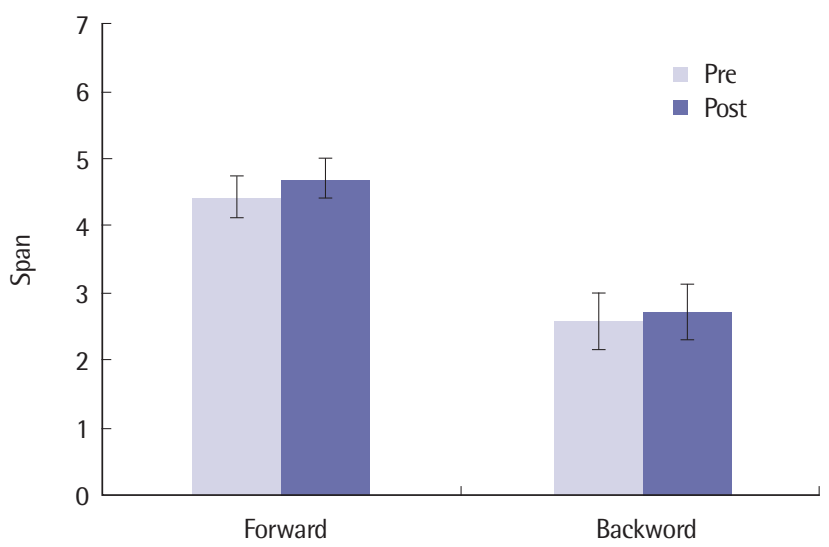

Figure 8. Pre-post comparison of digit forward and backward span tasks.

숫자 거꾸로 따라말하기

작업기억 중재 실시 전후에 숫자 거꾸로 따라말하기 과제 숫자폭 의 차이가 유의미한지를 알아보기 위해 분석한 결과, 중재 후 숫자 폭이 유의하게 증가하지 않았다 $(Z=-.577, p>.05)$. 즉 Figure 8과 같 이 중재 전 숫자 바로 따라말하기 숫자폭이 2.57 에서 중재 후에는 2.71로 증가하였지만 유의하지 않았다.

단어 바로 및 거꾸로 따라말하기 과제 점수 전후 비교 단어 바로 따라말하기

작업기억 중재 실시 전후에 단어 바로 따라말하기 과제 단어폭 의 차이가 유의미한지를 알아보기 위해 분석한 결과, 중재 후 단어 폭이 유의하게 증가하였다 $(Z=-2.000, p<.05)$. 즉 Figure 9 와 같이 중재 전 단어 바로 따라말하기 단어폭이 2.71에서 중재 후에는 3.29 로 증가하였다. 


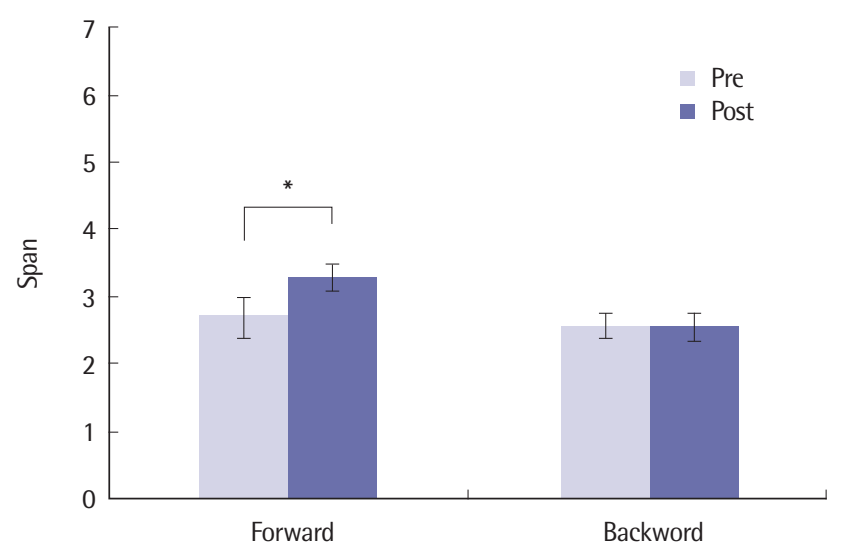

Figure 9. Pre-post comparison of word forward and backward span tasks. ${ }^{*} p<.05$.

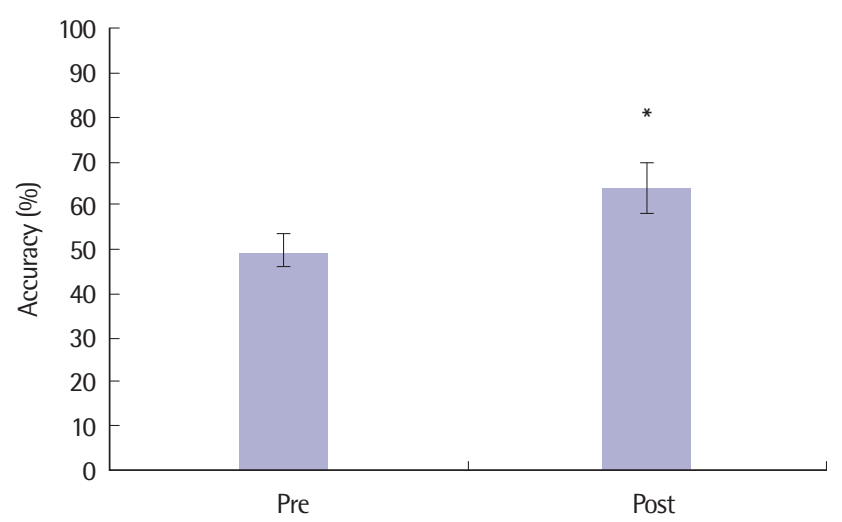

Figure 10. Pre-post comparison of accuracy on sentence comprehension task. ${ }^{*} p<.05$.

단어 거꾸로 따라말하기

작업기억 중재 실시 전후에 단어 거꾸로 따라말하기 과제 단어 폭의 차이가 유의미한지를 알아보기 위해 분석한 결과, 중재 후 단 어폭이 유의하게 증가하지 않았다 $(Z=.000, p>.05)$. 즉 Figure 9 와 같이 중재 전 단어 거꾸로 따라말하기 단어폭이 2.57 에서 중재 후 에는 2.57 로 동일하였다.

\section{문장이해과제로의 일반화 효과}

작업기억 중재 실시 전후에 문장이해과제 정확도(\%)에 유의한 차이가 있는지 알아보기 위해 분석한 결과, 중재 후 문장이해 정확 도가 유의하게 증가한 것으로 나타났다 $(Z=-2.197, p<.05)$. 즉 Figure 10 과 같이 중재 전 문장이해과제 정확도가 49.60 에서 중재 후 에는 63.89로 증가하였다.

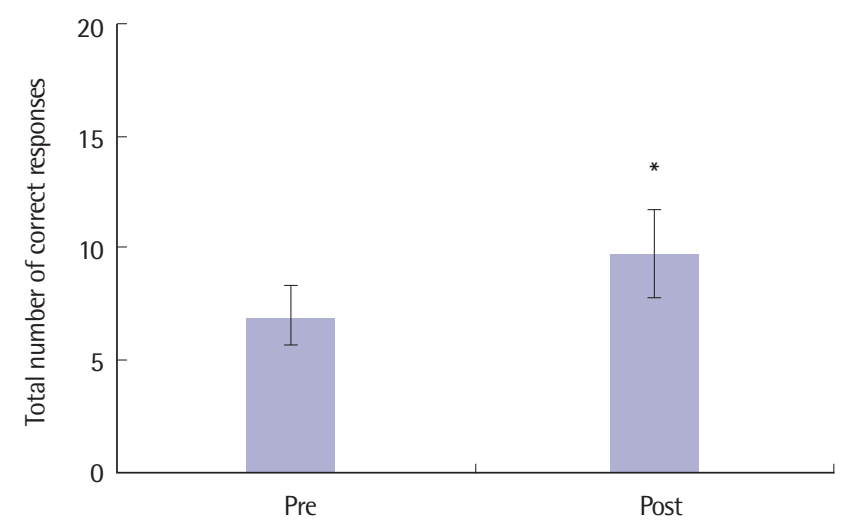

Figure 11. Pre-post comparison of total number of correct responses on categorical word fluency task (animal). ${ }^{*} p<.05$.

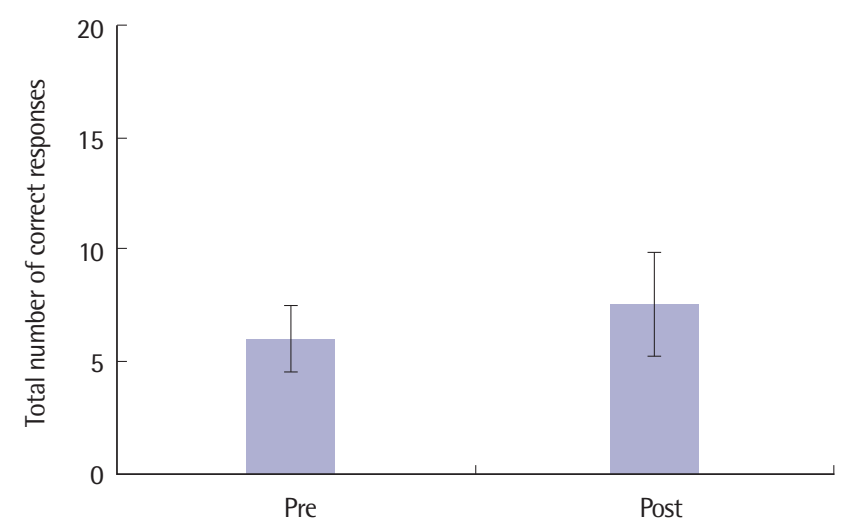

Figure 12. Pre-post comparison of total number of correct responses on categorical word fluency task (market).

단어유창성 과제로의 일반화 효과

범주유창성 과제총 정반응수 전후 비교

작업기억 중재 실시 전후에 범주유창성 과제 총 정반응 수의 차 이가 유의미한지를 알아보기 위해 두 가지 범주, 즉 동물과 가게물 건 범주유창성 과제에서의 총 정반응 수를 분석하였다.

범주유창성 과제 중 동물범주: 작업기억 중재 실시 전후에 동물 범주유창성 과제 총 정반응 수의 차이가 유의미한지를 알아보기 위해 분석한 결과, 중재 후 동물 범주유창성 과제 총 정반응 수가 유의하게 증가한 것으로 나타났다 $(Z=-2.232, p<.05)$. 즉, Figure 11 과 같이 중재 전 총 정반응 수가 7.00에서 중재 후에는 9.71로 증가 하였다.

범주유창성 과제 중 가게물건범주: 작업기억 중재 실시 전후에 가게물건 범주유창성 과제 총 정반응 수의 차이가 유의미한지를 알아보기 위해 분석한 결과, 중재 후 가게물건 범주유창성 과제 총 정반응 수가 유의하게 증가하지 않았다 $(Z=-1.160, p>.05)$. 즉, Fig- 


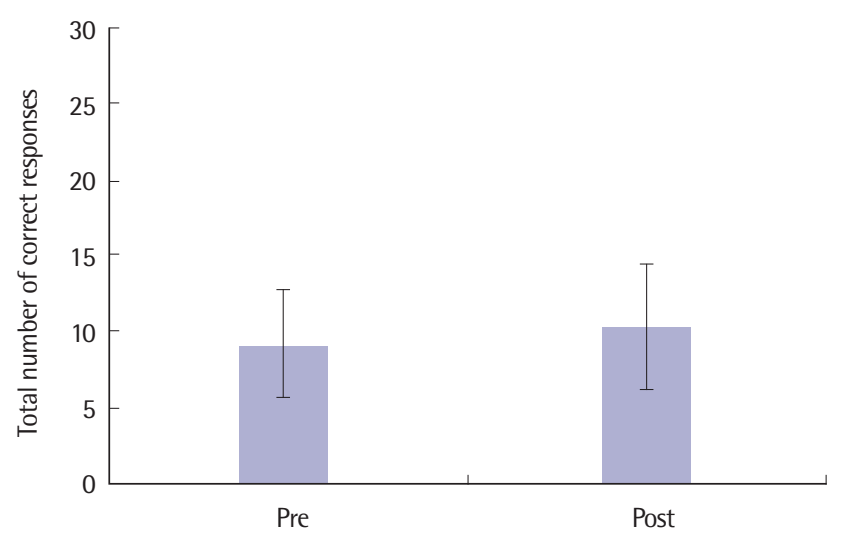

Figure 13. Pre-post comparison of total number of correct responses on phonetic word fluency task.

ure 12 와같이 중재 전 총 정반응 수가 6.00 에서 중재 후에는 7.57로 증가하였으나 그차이가 통계적으로 유의하지 않았다.

음소유창성 과제 총 정반응수 전후 비교

작업기억 중재 실시 전후에 음소유창성 과제 총 정반응 수의 차 이가 유의미한지를 알아보기 위해 세 가지 음소, 즉 ‘ㄱ, ㅅ, ’음 소유창성 과제에서의 총 정반응 수를 분석하였다. 그 결과, 중재 후 음소유창성 과제 총 정반응 수가 유의하게 증가하지 않았다 $(\mathrm{Z}=$ -.137, $p>$.05). 즉, Figure 13과 같이 중재 전 음소유창성 과제 총 정 반응 수가 9.14에서 중재 후에는 10.29 로 증가하였지만 통계적으로 유의하지 않았다.

\section{논의 및 결론}

본 연구의 목적은 경도-중등도 실어증환자를 대상으로 의미범주 기반 작업기억 중재 후 (1) 중재 작업기억 과제(의미범주 작업기억 과 제)의 단어폭에 유의미한차이가 있는지, (2) 비중재작업기억 과제(숫 자 및 단어폭 과제) 기억폭에 유의미한 차이가 있는지, (3) 문장이해 과제 정확도에 유의미한 차이가 있는지, (4) 단어유창성 과제 수행력 에 유의미한차이가 있는지에 관한 일반화 효과를 알아보는 것이다.

총 7명의 경도-중등도 실어증환자를 대상으로 한 의미범주기반 작업기억 중재를 실시한 결과, 중재 작업기억 과제인 의미범주 작업 기억 과제의 단어폭이 증가하였고, 그 증가가 통계적으로 유의한 차이를 나타냈다. 즉, 실어증환자를 대상으로 한 의미범주기반 작 업기억 중재가 중재 작업기억 과제의 수행력 증가에 도움을 주는 것으로 나타났다. 이러한 결과는 의미범주기반 작업기억 중재가 의 미범주 작업기억 과제의 수행력 증가에 효과가 있다는 것을 나타내 며, 실어증환자를 대상으로 작업기억 중재를 한 선행연구들과 일치
한다(Eom, 2015; Francis et al., 2003; Kalinyak-Fliszar et al., 2011; Martin et al., 2009; Salis, 2012; Vallat et al., 2005; Winans et al., 2012). 그러나 실어증환자를 대상으로 한 기존의 작업기억 중재는 대부분 핵심훈련, 즉 작업기억의 저장과 처리를 사용하는 특정 과 제(따라말하기, 듣기폭 과제 등)를 반복하는 중재기법을 대부분 적 용하였다. 대상자 또한 한 명의 피험자인 파일럿 연구 형태이거나 전도성 실어증환자군에 한정되어있어 실어증환자 전반에 그 결과 를 일반화하기에는 무리가 있다. 이에 본 연구에서는 과제 반복을 통해 작업기억의 용량(capacity)을 확장하는 것과 더불어 순차적 으로 의미범주 단서를 제시함으로써 작업기억을 효율적으로 사용 하는 기억전략과 시청각적 자극을 활용할 수 있도록 하는 작업기 억 중재를 실시하였다. 또한 적은 수이긴 하나 다양한 유형의 실어 증환자를 대상으로 의미범주기반 작업기억 중재를 실시함에 따라 작업기억이 향상되었다는 데 의미가 있다. 한가지 흥미로운 것은 참여자들이 단어를 회상하는 동안 목표범주의 단어 뒤에 즉시 책 상을 치는 횟수를 분석한 결과, 단어회상 정반응 수와 책상을 치는 횟수가 반비례하는 양상을 나타내었다. 이는 언어처리과정에서 작 업기억의 저장과 처리기능은 제한된 작업기억 용량을 공유하기 때 문에 한 번에 초과된 요구가 들어오면 저장과 처리의 불균형이 나 타난다는 Just와 Carpenter (1992) 모델을 반영하는 것이라 해석된 다. 또한 요구되는 작업기억이 사용 가능한 한도에 대한 개인차가 있으며 이러한 작업기억의 용량이 적은 사람은 작업기억의 요구가 증가함에 따라 수행력이 감소할 것이라는 가정과도 일치한다 (Jaeggi et al., 2008).

중재의 일반화 효과로 살펴본 비중재 작업기억 과제와 문장이해 과제 및 단어유창성 과제에서는 각각 상이한 결과를 나타냈다. 먼 저, 비중재 작업기억 과제인 숫자 및 단어폭 과제에서는 단어 바로 따라말하기를 제외한 숫자 바로 및 거꾸로 따라말하기에서는 기억 폭의 증가가 통계적으로 유의한 차이를 나타내지 않았고, 단어 거 꾸로 따라 말하기에서는 기억폭의 변화가 없었다. 이러한 결과는, 작업기억 중재의 효과를 비중재 작업기억으로 일반화하기에는 제 한적이라는 것을 나타낸다. 이는 Winans 등(2012)의 연구에서 중 도의 실어증환자를 대상으로 듣기폭 과제에 기초한 작업기억 중재 결과, 듣기폭과 문장이해력에서는 유의한 향상을 보였지만 다른 작 업기억 과제에 대한 일반화는 나타나지 않았다는 연구결과와 일치 한다. 또한 지능, 억제, 언어기능, 수학기능 등 여러 인지기능에서 훈 련 효과가 비일관적으로 나타나는 이유를 작업기억의 영역 특수성 으로 설명하며, 영역이 일치할 때 더 큰 효과를 보인다는 연구결과 와도 일치한다(Melby-Lervåg \& Hulme, 2013; Seo \& Kim, 2014). 또한 Sung (2010)의 연구에서 거꾸로 따라지시하기 과제보다는 바 
로 따라지시하기가, 의미적 처리과정이 포함된 단어보다 숫자가 실 어증환자의 문장처리과정을 예측하는 변수로 나타났다. 즉, 작업기 억 과제에서 단어는 숫자보다 의미적 처리가 더 많이 요구되는 과제 로 실어증환자는 단어보다 숫자 과제에서 더 높은 수행을 나타낸 다고 하였다. 본 연구에서도 비중재 작업기억 과제에서 단어폭 따 라말하기 수행력보다 숫자폭 따라말하기 수행력이 더 높게 나타나 Sung (2010)의 연구결과와 일치하였다. 그러나 중재효과에 있어서 는 단어 바로 따라말하기에서만 유의한 중재효과가 있었는데, 이 는 의미범주기반 작업기억 중재에서 사용한 작업기억 과제가 일련 의 단어목록을 듣고 수행하는 것으로 단어 바로 따라말하기와 비 슷한 양식의 과제를 사용하였기 때문이라고 생각한다.

또한 문장이해과제 정확도가 증가하였고, 그 증가가 통계적으로 유의하였다. 즉, 작업기억 중재가 문장이해로 일반화 효과가 나타 났다. 본 연구는 문장처리가 요구되지 않으며 의미적으로나 통사적 으로 단서를 사용할 수 없는 일련의 단어목록을 듣고 마지막 단어 를 회상하는 작업기억 과제를 사용하였다. 또한 이를 토대로 개발 한 작업기억 중재는 의미범주화를 통한 기억전략과 시·청각적 자 극을 활용할 수 있도록 고안된 중재기법이다. 이러한 전략이 내재 된 작업기억 중재는 공통적인 인지적 기제를 요하는 문장이해과 제, 즉 의미적 요소가 통제된 한국어 문장의 규범·비규범 어순 및 능동·피동관계에 따른 문장이해를 평가하는 과제에도 긍정적인 영향을 미쳤다. 직접적인 문장이해 중재를 실시하지 않았음에도 불구하고 작업기억이 향상됨에 따라 문장이해능력이 향상되었다 는 것은 의미있는 결과로 해석할 수 있다. 이러한 결과는 문장 따라 말하기를 활용한 작업기억 중재(Eom, 2015; Francis et al., 2003; Kalinyak-Fliszar et al., 2011; Martin et al., 2009)나 듣기폭 과제를 사용한 중재(Winans et al., 2012), 문단수준의 읽기 과제를 사용한 중재(Mayer \& Murray, 2002)의 결과와도 일치한다. 작업기억 용량 과 문장이해능력 간의 상관관계는 여러 연령층 및 언어장애군을 대상으로 연구되어 왔다(Baddeley, Logie, Nimmo-Smith, \& Brereton, 1985; Daneman \& Carpenter, 1980, 1983; De Beni, Palladino, Pazzaglia, \& Cornoldi, 1995; Dixon, LeFevre, \& Twilley, 1988; Ehrlich, Brébion, \& Tardieu, 1994; Masson \& Miller, 1983). 특히 실어 증 분야에서도 작업기억과 문장이해능력 간의 상관관계는 다양하 게 보고되고 있다(Friedmann \& Gvion, 2003; Gordon, 1983; Kim et al., 2013; Murray, Ballard, \& Karcher, 2004; Sung et al., 2009; Tompkins, Bloise, Timko, \& Baumgaertner, 1994; Vukovic et al., 2008; Ween, Verfaellie, \& Alexander, 1996). 문장이해를 위해서는 문장을 구성하는 다양한 단어들의 의미를 활성화하고 정보를 유 지하며, 해석하는 등 작업기억과 관련된 일련의 과정이 요구된다
(Just \& Carpenter, 1992). 따라서 작업기억은 문장이해와 관련된 근본적인 인지적 기제로서 설명되어왔다. 이러한 이론적 배경에 따 르면, 본 연구의 결과는 작업기억 중재를 통하여 작업기억 용량을 확장하고, 기억전략을 효율적으로 사용할 수 있게 함으로써 문장 처리를 보다 용이하게 하여 문장이해능력으로의 향상이 일어난 것 으로 해석할 수 있다. 이러한 결과를 다양한 실어증유형의 환자에 게 공통적으로 적용할 수 있다는 점에서작업기억 중재는 임상적으 로 의미가 크다. 또한 작업기억 중재를 통해 문장이해로의 일반화 효과가 있다는 결과는 치료효율성 극대화 측면에서 의미가 있다.

마지막으로 단어유창성 과제 중에서도 중재에 포함된 범주인 동 물 범주유창성 과제에서는 총 정반응 수가 증가하였고, 그 증가가 통계적으로 유의하였다. 그러나 중재에 포함되지 않은 범주인 가게 물건 범주유창성 과제에서는 총 정반응 수가 증가하였으나 그 증가 가 통계적으로 유의하지 않았다. 또한 음소유창성 과제에서도 총 정반응 수가 증가하였으나 그 증가가 통계적으로 유의하지 않았다. 이러한 결과는 의미범주기반 작업기억 중재 후 동물 범주유창성 과 제에는 일반화 효과가 있었으나 가게물건 범주유창성 과제, 음소 유창성 과제로의 일반화 효과는 제한적이라는 것을 나타낸다. 의 미단서에 의한 이름대기에서는 심성어휘집(mental lexicon)으로의 의미적 탐색(semantic search)이 수행되며, 이것은 의미지식의 내적 체계에 강하게 의존한다. 반면 음소단서에 의한 이름대기에서는 주 어진 음운론적 단서에 해당하는 새로운 범주를 생성하기 위해 어 휘 탐색 시 의미단서보다 더 많은 노력이 필요하다(Martin, Wiggs, LaLonde, \& Mack, 1994). 본 연구 결과에서도 중재 전·후 평가에 서 음소유창성 과제보다 범주유창성 과제에서 산출한 전체 어휘 수가 더 많았다. 이는 단어유창성 과제에서 의미체계 안에서 어휘 정보를 찾는 과정과 함께 산출 전략을 탐색하는 실어증환자의 인 지적 측면이 어휘 산출에 영향을 준다는 Choi와 Sung (2014)의 연 구결과와 일치한다. 또한 중재 시 의미적 처리의 활성화를 위한 의 미범주화 기억전략를 사용하였기 때문에 음소유창성 과제와 달리 범주유창성 과제에서 일반화 효과가 나타난 것으로 사료된다. 한 편, 범주유창성 과제 중 동물 범주유창성 과제에서는 중재 후 유의 한 증가가 나타났고, 가게 범주유창성 과제에서는 중재 후 정반응 수는 증가하였지만 통계적으로 유의하지 않았다. 이는 동물범주가 작업기억 중재프로토콜에서 사용된 범주 중 하나로 의미범주화 기 억전략을 사용한 작업기억 중재로 인한 효과가 극대화된 것으로 생각한다. 작업기억 용량과 단어유창성 간의 상관관계는 여러 연령 층 및 언어장애군을 대상으로 연구되어 왔으며(Rosen \& Engle, 1997; Troyer, Moscovitch, \& Winocur, 1997), 특히 실어증 분야에 서도 작업기억과 단어유창성 능력 간의 상관관계가 보고되고 있다 
(Adams et al., 1989; Choi \& Sung, 2014; Kim, Sim, \& Kim 2004). 한정된 시간 내에 주어진 단서에 적절한 단어를 가능한 많이 탐색 해야 하는 단어유창성 과제는 즉각적인 주의, 의미 및 어휘체계와 같은 단어지식, 서술적 구어기억으로부터 인출하는 능력, 이 모든 과정을 조율하는 집행능력이 필요하다(Ruff, Light, Parker, \& Levin, 1997). 이에 따라 작업기억은 단어유창성과 관련된 인지적 기제로 서 설명되어왔다. 그럼에도 불구하고 작업기억 중재를 함으로써 단 어유창으로의 일반화 효과를 살펴본 연구는 거의 없다. 이러한 이 론적 배경에 따라 본 연구는 작업기억 중재에 따른 단어유창성으 로의 일반화 효과를 알아보았고 제한적이긴 하나 동물 범주유창성 으로의 일반화 효과를 나타내었다는 데 의미가 있다.

본 연구의 결과를 요약하면 다음과 같다. 첫째, 작업기억 중재 후 의미범주 작업기억 과제의 단어폭이 유의미하게 증가하였고, 그 증 가가 통계적으로 유의한 차이를 나타냈다. 둘째, 비중재 작업기억 과제에서는 단어 바로 따라말하기를 제외한 숫자 바로 및 거꾸로 따라말하기와 단어 거꾸로 따라말하기에서는 기억폭의 증가는 있 었으나 그 증가가 통계적으로 유의한 차이를 나타내지 않았다. 셋 째, 작업기억 중재 후 문장이해과제 정확도가 유의미하게 증가하였 고, 그 증가가 통계적으로 유의한 차이를 나타냈다. 넷째, 작업기억 중재 후 단어유창성 과제 중 동물 범주유창성 점수는 유의미하게 증가하였고, 그 증가가 통계적으로 유의한 차이를 나타냈다. 그러 나가게 범주유창성과 음소유창성 점수에서 보인 증가는 통계적으 로 유의한 차이를 나타내지 않았다. 이와 같은 결과는 본 연구에 사 용된 의미범주기반 작업기억 중재가 실어증환자의 작업기억을 촉 진, 확장하는 기법으로 실어증환자의 작업기억뿐만 아니라 작업기 억과 관련된 인지적 기제를 사용하는 문장이해에도 긍정적인 영향 을 미칠 수 있음을 시사한다. 다시 말해 직접적인 문장이해와 관련 된 중재를 하지 않았음에도 불구하고 작업기억의 향상을 통해 문 장이해로의 일반화 효과가 나타났다고 해석할 수 있다. 이에 본 연 구는 실어증환자의 작업기억이 언어처리능력과 관련이 있다는 선 행연구 결과(Caspari et al., 1998; Seniów, Litwin, Litwin, Leśniak, \& Członkowska, 2009; Sung et al., 2009; Tompkins et al., 1994) 및 작업기억 손상과 관련된 치료가 기억능력과 더불어 실어증환자의 언어능력에도 향상을 가져온다는 기존 연구들을 입증하고 있다 (Francis et al., 2003; Koenig-Bruhin \& Studer-Eichenberger, 2007; Mayer \& Murray, 2002; Salis, 2012). 반면 비중재 작업기억 과제와 단어유창성 과제에서는 중재 및 일반화 효과가 제한적이었다. 이러 한 결과는 작업기억의 영역특수성에 따라 지능, 억제, 언어기능, 수 학기능 등 여러 인지기능에서의 훈련은 영역이 일치할 때 더 큰 효 과를 보인다는 연구결과와 일치한다(Melby-Lervåg \& Hulme, 2013;
Seo \& Kim, 2014).

본 작업기억 중재는 작업기억 용량을 늘리고 기억전략을 효율적 으로 사용하도록 훈련하는 작업기억 중재 프로토콜을 개발하여 다양한 실어증환자에게 공통적으로 적용하였다는 점, 언어능력으 로의 일반화 효과를 살펴보았다는 데 의의가 있다. 또한 작업기억 중재를 통해 문장이해로의 일반화 효과가 있다는 결과는 치료효 율성 극대화 측면에서 의미가 있다. 그러나 본 연구의 대상의 수는 실어증환자 7 명으로 비교적 적은 편이다. 작업기억 중재의 효과를 정확히 예측하고 각 과제 결과 간의 상관관계를 알아보기 위해서 향후 실어증 유형별 대상의 수를 늘려 다양하게 적용 할 필요가 있 다. 또한 작업기억 중재와 사전·사후평가에서 사용된 작업기억 과 제, 단어유창성 과제는 모두 구어로 반응해야 하는 과제이다. 이러 한 과제는 말실행증을 포함한 말운동장애를 동반한 실어증환자에 게는 적합하지 않다(Tompkins et al., 1994). 실제 본 연구에 참여한 실어증환자 7명 중 4명은 말실행증을 동반하였다. 향후에는 이로 인한 참여자들의 과제 수행에 영향을 최소화하기 위하여 말실행증 동반유무에 대한 대상자 통제가 필요할 것이다. 마지막으로 본 연 구에서 사용한 문장이해과제는 의미적 요소가 통제된 한국어 문 장의 규범·비규범 어순 및 능동·피동관계에 따른 문장이해를 평 가하는 과제이다. 추후 의미적 요소가 포함된 문장이해를 평가하 는 과제로의 일반화 효과를 알아보기 위한 연구도 필요할 것이다.

\section{REFERENCES}

Adams, M. L., Reich, A. R., \& Flowers, C. R. (1989). Verbal fluency characteristics of normal and aphasic speakers. Journal of Speech, Language, and Hearing Research, 32, 871-879.

Ahn, G. M. (2010). The effect of working memory enhancement program on word fluency and sentence comprehension in dementia of Alzheimer's type patients (Master's thesis). Deagu University, Daegu, Korea.

Baddeley, A. (1986). Working memory. Oxford: Clarendon Press.

Baddeley, A., Logie, R., Nimmo-Smith, I., \& Brereton, N. (1985). Components of fluent reading. Journal of Memory and Language, 24, 119-131.

Baldo, J. V., Ludy, C., Wilkins, D., \& Dronkers, N. (2002). Impaired category but preserved letter fluency in patients with severe Wernicke's aphasia. Brain and Language, 83, 26-28.

Brooks, D. N. (1987). Measuring neuropsychological and functional recovery. In H. S. Levin \& J. Grafman (Eds.), Neurobehavioral recovery from head injury (pp. 57-72). New York, NY: Oxford University Press.

Bruyer, R., \& Tuyumbu, B. (1980). Verbal fluency and lesion of the cerebral 
cortex. L'Encephale, 6, 287-297.

Caspari, I., Parkinson, S. R., LaPointe, L. L., \& Katz, R. C. (1998). Working memory and aphasia. Brain and Cognition, 37, 205-223.

Cho, S. J., \& Kim, S. J. (2002). Relationships to working memory and Comprehension of active and passive sentences in Korean aphasics. Proceedings of the Korean Academy of Speech-Language Pathology and Audiology Conference, 62-69.

Choi, H. M., \& Sung, J. E. (2014). The Relationship between working memory capacity and the abilitye of generative naming in persons with aphasia. Journal of Speech-Language \& Hearing Disorders, 23, 23-34.

Cicerone, K. D., Dahlberg, C., Kalmar, K., Langenbahn, D. M., Malec, J. F., Bergquist, T. F., ... \& Herzog, J. (2000). Evidence-based cognitive rehabilitation: recommendations for clinical practice. Archives of Physical Medicine and Rehabilitation, 81, 1596-1615.

Cicerone, K. D., Dahlberg, C., Malec, J. F., Langenbahn, D. M., Felicetti, T., Kneipp, S., ... \& Laatsch, L. (2005). Evidence-based cognitive rehabilitation: updated review of the literature from 1998 through 2002. Archives of Physical Medicine and Rehabilitation, 86, 1681-1692.

Coehlo, C., Kimbarow, M., \& Boyle, M. (1987). A longitudinal study of word fluency response strategies in two aphasic subjects. Proceedings of the 17th Annual Clinical Aphasiology Conference, Lake of the Ozarks, MO.

Conners, F. A., Rosenquist, C. J., Arnett, L., Moore, M. S., \& Hume, L. E. (2008). Improving memory span in children with Down syndrome. Journal of Intellectual Disability Research, 52, 244-255.

Daneman, M., \& Carpenter, P. A. (1980). Individual differences in working memory and reading. Journal of Verbal Learning and Verbal Behavior, 19, 450-466.

Daneman, M., \& Carpenter, P. A. (1983). Individual differences in integrating information between and within sentences. Journal of Experimental Psychology: Learning, Memory, and Cognition, 9, 561-583.

De Beni, R., Palladino, P., \& Pazzaglia, F. (1995). Influenza della memoria di lavoro e delle abilità metacognitive e sintattiche nella difficoltà specifica di comprensione della lettura. Giornale Italiano di Psicologia, 22, 615-640.

De Beni, R., Palladino, P., Pazzaglia, F., \& Cornoldi, C. (1998). Increases in intrusion errors and working memory deficit of poor comprehenders. Quarterly Journal of Experimental Psychology: Section A, 51, 305-320.

Dixon, P., LeFevre, J. A., \& Twilley, L. C. (1988). Word knowledge and working memory as predictors of reading skill. Journal of Educational Psychology, 80, 465-472.

Duncan, P. W., Goldstein, L. B., Matchar, D., Divine, G. W., \& Feussner, J. (1992).
Measurement of motor recovery after stroke: outcome assessment and sample size requirements. Stroke, 23, 1084-1089.

Dunn, N. D., Russell, S. S., \& Drummond, S. S. (1989). Effect of stimulus context and response coding variables on word retrieval performances in dysphasia. Journal of Communication Disorders, 22, 209-223.

Ehrlich, M. F., Brébion, J., \& Tardieu, H. (1994). Working-memory capacity and reading comprehension in young and older adults. Psychological Research, 56, 110-115.

Eom, B. R. (2015). The effects of sentence repetition-based working memory treatment on sentence comprehension abilities in individuals with aphasia (Master's thesis). Ewha Womans University, Seoul, Korea.

Francis, D., Clark, N., \& Humphreys, G. (2003). The treatment of an auditory working memory deficit and the implications for sentence comprehension abilities in mild "receptive" aphasia. Aphasiology, 17, 723-750.

Friedmann, N., \& Gvion, A. (2003). Sentence comprehension and working memory limitation in aphasia: a dissociation between semantic-syntactic and phonological reactivation. Brain and Language, 86, 23-39.

Goodglass, H., \& Kaplan, E. (1983). The assessment of aphasia and related disorders. Philadelpia, PA: Lea \& Febiger.

Gordon, W. P. (1983). Memory disorders in aphasia. I: Auditory immediate recall. Neuropsychologia, 21, 325-339.

Grossman, M. (1981). A bird is a bird is a bird: making reference within and without superordinate categories. Brain and Language, 12, 313-331.

Hasher, L., \& Zacks, R. T. (1979). Automatic and effortful processes in memory. Journal of Experimental Psychology: General, 108, 356-388.

Hyun, J. M., Sung, J. E., Jeong, J. H., Kang, H. J., \& Kim, H. J. (2013). Effects of syntactic complexity on a case marker processing task in people with mild cognitive impairment. Communication Sciences \& Disorders, 18, 3546.

Jaeggi, S. M., Buschkuehl, M., Jonides, J., \& Perrig, W. J. (2008). Improving fluid intelligence with training on working memory. Proceedings of the National Academy of Sciences, 105, 6829-6833.

Janowsky, J. S., Shimamura, A. P., Kritchevsky, M., \& Squire, L. R. (1989). Cognitive impairment following frontal lobe damage and its relevance to human amnesia. Behavioral Neuroscience, 103, 548-560.

Just, M. A., \& Carpenter, P. A. (1992). A capacity theory of comprehension: individual differences in working memory. Psychological Review, 99, 122149.

Kalinyak-Fliszar, M., Kohen, F., \& Martin, N. (2011). Remediation of language processing in aphasia: improving activation and maintenance of linguistic 
representations in (verbal) short-term memory. Aphasiology, 25, 1095-1131.

Kane, M. J., \& Engle, R. W. (2000). Working-memory capacity, proactive interference, and divided attention: limits on long-term memory retrieval. Journal of Experimental Psychology: Learning, Memory, and Cognition, 26, 336-358.

Kang, Y., Chin, J. H., Na, D. L., Lee, J., \& Park, J. S. (2000). A normative study of the Korean version of Controlled Oral Word Association Test (COWAT) in the elderly. Korean Journal of Clinical Psychology, 19, 385-392.

Kim, A. R., Sim, H. S., \& Kim, Y. T. (2004). A comparison of generative naming characteristics in fluent and non-fluent aphasics. Speech Sciences, 11, 151-161.

Kim, H. H., \& Na, D. L. (2001). Paradise-Korean version-Western Aphasia Battery (K-WAB). Seoul: Paradise Welfare Foundation.

Kim, J. S., \& Kang, S. K. (2005). The effect of superordinate categorization training on naming ability of Alzheimer's disease patients. Communication Disorders, 28, 93-114.

Kim, Y. B., Sung, J. E., \& Kim, Y. H. (2013). Verbal and non-verbal working memory capacity and its relation to sentence comprehension in aphasia. Journal of Speech-Language \& Hearing Disorders, 22, 1-16.

Ko, U. (2004). A study on aphasic's visual semantic memory observed in their performance of object-color pairing tasks, Journal of Speech-Language \& Hearing Disorders, 13, 1-14.

Koenig-Bruhin, M., \& Studer-Eichenberger, F. (2007). Therapy of short-term memory disorders in fluent aphasia: a single case study. Aphasiology, 21, 448-458.

Lee, J. S. (1992). A study on the effect of the phonemic and semantic categorization stimulus conditions on word recall in reading disabled children (Master's thesis). Ewha Womans University, Seoul, Korea.

Lee, O. B. (2003). The effect of group therapy using a cooperative and cognitive intervention program in aphasics (Doctoral dissertation). Daegu University, Daegu, Korea.

Lendrem, W., \& Lincoln, N. B. (1985). Spontaneous recovery of language in patients with aphasia between 4 and 34 weeks after stroke. Journal of Neurology, Neurosurgery \& Psychiatry, 48, 743-748.

Lundqvist, A., Grundström, K., Samuelsson, K., \& Rönnberg, J. (2010). Computerized training of working memory in a group of patients suffering from acquired brain injury. Brain Injury, 24, 1173-1183.

Malouin, F., Belleville, S., Richards, C. L., Desrosiers, J., \& Doyon, J. (2004). Working memory and mental practice outcomes after stroke. Archives of Physical Medicine and Rehabilitation, 85, 177-183.
Martin, A., Wiggs, C. L., Lalonde, F., \& Mack, C. (1994). Word retrieval to letter and semantic cues: a double dissociation in normal subjects using interference tasks. Neuropsychologia, 32, 1487-1494.

Martin, N., Kohen, F., McCluskey, M., Kalinyak-Fliszar, M., \& Gruberg, N. (2009). Treatment of a language activation maintenance deficit in Wernicke's aphasia. Proceedings of the 39th Annual Clinical Aphasiology Conference, Keystone, CO.

Masson, M. E., \& Miller, J. A. (1983). Working memory and individual differences in comprehension and memory of text. Journal of Educational Psychology, 75, 314-318.

Mayer, J. F., \& Murray, L. L. (2002). Approaches to the treatment of alexia in chronic aphasia. Aphasiology, 16, 727-743.

McNeil, M. R., \& Pratt, S. R. (2001). Defining aphasia: some theoretical and clinical implications of operating from a formal definition. Aphasiology, $15,901-911$.

McNeil, M., Sung, J. E., Pratt, S., Szuminsky, N., Kim, A., Ventura, M., ... \& Musson, N. (2008). Concurrent validation of the Computerized Revised Token Test (CRTT) and three experimental reading versions (CRTT-R) in normal elderly individuals and persons with aphasia. Proceedings of the 38th Annual Clinical Aphasiology Conference, Jackson Hole, WY.

Melby-Lervåg, M., \& Hulme, C. (2013). Is working memory training effective? A meta-analytic review. Developmental Psychology, 49, 270-291.

Montgomery, J. W. (2000a). Relation of working memory to off-line and realtime sentence processing in children with specific language impairment. Applied Psycholinguistics, 21, 117-148.

Montgomery, J. W. (2000b). Verbal working memory and sentence comprehension in children with specific language impairment. Journal of Speech, Language, and Hearing Research, 43, 293-308.

Morrison, A. B., \& Chein, J. M. (2011). Does working memory training work? The promise and challenges of enhancing cognition by training working memory. Psychonomic Bulletin \& Review, 18, 46-60.

Murray, L. L. (2004). Cognitive treatments for aphasia: should we and can we help attention and working memory problems? Journal of Medical SpeechLanguage Pathology, 12, 21-38.

Murray, L., Ballard, K., \& Karcher, L. (2004). Linguistic specific treatment: just for Broca's aphasia? Aphasiology, 18, 785-809.

Naus, M. J. (1974). Memory search of categorized lists: a consideration of alternative self-terminating search strategies. Journal of Experimental Psychology, 102, 992-1000.

Park, N. W., \& Ingles, J. L. (2001). Effectiveness of attention rehabilitation af- 
ter an acquired brain injury: a meta-analysis. Neuropsychology, 15, 199210 .

Park, T., Park, S., \& Kim, T. (2006). The effects of Korean lexical characteristics on memory span. Korean Journal of Cognitive Science, 17, 15-27.

Rhee, K. Y. (1991). Korean category norms: survey on exemplar frequency norm, typicality, and features. Korean Journal of Experimental and Cognitive Psychology, 3, 131-160.

Robertson, I. H., \& Murre, J. M. (1999). Rehabilitation of brain damage: brain plasticity and principles of guided recovery. Psychological Bulletin, 125, 544575.

Rosen, V. M., \& Engle, R. W. (1997). The role of working memory capacity in retrieval. Journal of Experimental Psychology: General, 126, 211-227.

Ruff, R. M., Light, R. H., Parker, S. B., \& Levin, H. S. (1997). The psychological construct of word fluency. Brain and Language, 57, 394-405.

Salis, C. (2012). Short-term memory treatment: patterns of learning and generalisation to sentence comprehension in a person with aphasia. Neuropsychological Rehabilitation, 22, 428-448.

Seniów, J., Litwin, M., Litwin, T., Leśniak, M., \& Członkowska, A. (2009). New approach to the rehabilitation of post-stroke focal cognitive syndrome: effect of levodopa combined with speech and language therapy on functional recovery from aphasia. Journal of the Neurological Sciences, 283, 214-218.

Seo, H. Y., \& Kim, C. B. (2014). Working memory training effects according to domain-specificity: a meta-analysism. Korean Journal of Cognitive and Biological Psychology, 26, 207-231.

Shin, H. J. (2003). A validation of the category norms collected through Internet. Korean Journal of Experimental Psychology, 15, 303-347.

Sung, J. E. (2010). Performances on short-term and working memory tasks and their relationships to aphasia severity and auditory comprehension in normal elderly adults and people with aphasia. Korean Journal of Communication Disorders, 15, 285-297.

Sung, J. E. (2011). The reliability and validity of short-term and working memory pointing tasks developed for clinical populations with speech and language disorders. Korean Journal of Communication Disorders, 16, 185-201.

Sung, J. E. (2015). Effects of syntactic structure on sentence comprehension ability as a function of the canonicity of word-order and its relation to working memory capacity in Korean-speaking elderly adults. Communication Sciences \& Disorders, 20, 24-33.

Sung, J. E., McNeil, M. R., Pratt, S. R., Dickey, M. W., Hula, W. D., Szuminsky, N. J., \& Doyle, P. J. (2009). Verbal working memory and its relationship to sentence-level reading and listening comprehension in persons with apha- sia. Aphasiology, 23, 1040-1052.

Swan, L., Otani, H., Loubert, P. V., Sheffert, S. M., \& Dunbar, G. L. (2004). Improving balance by performing a secondary cognitive task. British Journal of Psychology, 95, 31-40.

Tompkins, C. A., Bloise, C. G., Timko, M. L., \& Baumgaertner, A. (1994). Working memory and inference revision in braindamaged and normally aging adults. Journal of Speech, Language, and Hearing Research, 37, 896912.

Troyer, A. K., Moscovitch, M., \& Winocur, G. (1997). Clustering and switching as two components of verbal fluency: evidence from younger and older healthy adults. Neuropsychology, 11, 138-146.

Turley-Ames, K. J., \& Whitfield, M. M. (2003). Strategy training and working memory task performance. Journal of Memory and Language, 49, 446-468.

Vallat, C., Azouvi, P., Hardisson, H., Meffert, R., Tessier, C., \& Pradat-Diehl, P. (2005). Rehabilitation of verbal working memory after left hemisphere stroke. Brain Injury, 19, 1157-1164.

Van Zomeren, A. H., \& Van den Burg, W. (1985). Residual complaints of patients two years after severe head injury. Journal of Neurology, Neurosurgery \& Psychiatry, 48, 21-28.

Vukovic, M., Vuksanovic, J., \& Vukovic, I. (2008). Comparison of the recovery patterns of language and cognitive functions in patients with post-traumatic language processing deficits and in patients with aphasia following a stroke. Journal of Communication Disorders, 41, 531-552.

Wechsler, D. (2012). Korean-Wechsler Adult Intelligence Scale IV (K-WAIS-IV) (S. T. Hwang et al., Trans.). Daegu: Korea Psychology Co.

Ween, J. E., Verfaellie, M., \& Alexander, M. P. (1996). Verbal memory function in mild aphasia. Neurology, 47, 795-801.

Weiss, T., Hansen, E., Beyer, L., Conradi, M. L., Merten, F., Nichelmann, C., ... \& Zippel, C. (1994). Activation processes during mental practice in stroke patients. International Journal of Psychophysiology, 17, 91-100.

Westerberg, H., Jacobaeus, H., Hirvikoski, T., Clevberger, P., Östensson, M. L., Bartfai, A., \& Klingberg, T. (2007). Computerized working memory training after stroke: a pilot study. Brain Injury, 21, 21-29.

Winans, R., Hula, W., Friedman, B., Sperl, A., Swoyer, B., \& Doyle, P. (2012). Treatment of working memory in a patient with moderate aphasia. Proceedings of the 42nd Annual Clinical Aphasiology Conference, Lake Tahoe, CA.

Wright, H. H., Downey, R. A., Gravier, M., Love, T., \& Shapiro, L. P. (2007). Processing distinct linguistic information types in working memory in aphasia. Aphasiology, 21, 802-813. 
Appendix 1. 참여자별 사전-사후 평가 결과

\begin{tabular}{|c|c|c|c|c|c|c|c|c|c|c|c|}
\hline \multirow{3}{*}{$\begin{array}{l}\text { Pre } \\
\text { ID }\end{array}$} & \multicolumn{5}{|c|}{ COWAT } & \multirow{3}{*}{$\begin{array}{c}\text { Treated } \\
\text { WM } \\
\text { Span }\end{array}$} & \multicolumn{4}{|c|}{ Non treated WM } & \multirow{3}{*}{$\begin{array}{c}\text { Sentence } \\
\text { comprehension } \\
\text { Accuracy }\end{array}$} \\
\hline & \multicolumn{2}{|c|}{ Categorical } & \multicolumn{3}{|c|}{ Phonetic } & & \multicolumn{2}{|c|}{ Digit span } & \multicolumn{2}{|c|}{ Word span } & \\
\hline & Animal & Market & ᄀ & ० & 人 & & Forward & Backward & Forward & Backward & \\
\hline 1 & 7 & 7 & 0 & 3 & 0 & 1 & 4 & 2 & 3 & 3 & 16 \\
\hline 2 & 8 & 6 & 0 & 2 & 1 & 1.25 & 4 & 2 & 2 & 2 & 19 \\
\hline 3 & 11 & 10 & 9 & 10 & 9 & 3 & 5 & 4 & 4 & 3 & 24 \\
\hline 4 & 12 & 12 & 4 & 7 & 4 & 2.25 & 4 & 3 & 3 & 3 & 20 \\
\hline 5 & 5 & 1 & 2 & 0 & 0 & 1.5 & 6 & 2 & 3 & 3 & 14 \\
\hline 6 & 3 & 4 & 2 & 3 & 2 & 1.25 & 4 & 2 & 2 & 2 & 17 \\
\hline 7 & 3 & 2 & 2 & 2 & 2 & 1 & 4 & 3 & 2 & 2 & 15 \\
\hline \multirow[t]{2}{*}{ Post } & \multicolumn{5}{|c|}{ COWAT } & Treated & \multicolumn{4}{|c|}{ Non treated WM } & $\begin{array}{c}\text { Sentence } \\
\text { comprehension }\end{array}$ \\
\hline & \multicolumn{2}{|c|}{ Categorical } & \multicolumn{3}{|c|}{ Phonetic } & & \multicolumn{2}{|c|}{ Digit span } & \multicolumn{2}{|c|}{ Word span } & $A_{c}$ \\
\hline ID & Animal & Market & $\neg$ & 0 & 人 & Span & Forward & Backward & Forward & Backward & ALCUIC \\
\hline 1 & 9 & 6 & 0 & 2 & 0 & 1.5 & 4 & 3 & 3 & 3 & 26 \\
\hline 2 & 12 & 4 & 1 & 0 & 2 & 2 & 5 & 2 & 3 & 2 & 17 \\
\hline 3 & 16 & 16 & 7 & 9 & 7 & 4.75 & 6 & 4 & 4 & 3 & 33 \\
\hline 4 & 16 & 17 & 9 & 10 & 10 & 2.75 & 4 & 2 & 3 & 2 & 23 \\
\hline 5 & 7 & 3 & 1 & 0 & 0 & 2.75 & 6 & 3 & 4 & 3 & 18 \\
\hline 6 & 3 & 5 & 4 & 1 & 3 & 2 & 5 & 2 & 3 & 3 & 24 \\
\hline 7 & 5 & 2 & 1 & 2 & 3 & 2 & 3 & 3 & 3 & 2 & 20 \\
\hline
\end{tabular}

COWAT = Controlled Oral Word Association Test (Kang, Chin, Na, Lee, \& Park, 2000); WM= working memory.

Appendix 2. 의미범주 작업기억 과제 실시지침 및 채점기준

작업기억 과제의 단어목록은 중재 프로토콜의 단어목록과 동일한 방법으로 구성되었으며 제시방법도 동일하다. 단, 작업기억 과제에서는 각 단어폭당 3개의 세트가 제 시된다.

\section{지시사항}

1. 피검자에게 검사방법에 대해 충분히 설명한다.

"자, 지금부터 단어 여섯 개를 듣게 됩니다. 세 개의 단어 중 $\bigcirc \bigcirc$ (목표범주, 예: 동물)에 해당하는 단어가 나오면 즉시 책상을 치시고, 여섯 개의 단어 중 세 번째, 여섯 번째 단어를 기억해서 저에게 말해주세요. 예를 들어, 제가 '사과-버스-기린/토끼-휴지-지하철'이라고 하면 '기린' ' '토끼' 다음에는 손바닥으로 책상을 치고, 단어목록 을 다 들은 후에는 세 번째, 여섯 번째 단어인 '기린, 지하철'을 말해야 합니다."라고 하며 시범을 보인다.

2. 연습문항으로 연습해본다. "연습해보겠습니다. "토끼-국자-버스/수건-사자-지하철'”

-정반응 시: “네, 맞습니다."라고 말하고 1번 문항부터 시작한다.

-오반응 시: “아닙니다. 제가 ‘토끼-국자-버스/수건-사자-지하철'이라고 했으니 동물 범주인 ‘토끼', '사자’ 다음에는 손바닥으로 책상을 치고, 단어목록을 다 들은 후에 '토끼, 사자’라고 말해야 합니다. 다시 연습해보겠습니다. "버스-토마토-호랑이/사슴-비누-택시'."

3. 두 번째 연습문항의 정/오반응에 상관없이 1 번 문항으로 넘어간다. 두 번째 문항부터는 어떠한 도움도 주어서는 안 된다.

4. 단어 간 간격은 1초, 단어목록(word list) 간 간격은 2초로 불러주고, 각 단어목록의 마지막 단어는 음조를 약간 낮추어 불러준다.

5. 단어폭2의 모든 세트가 끝나면 단어폭3이 시작하기 전에 다음과 같이 지시한다. "자, 이제 아홉 개의 단어를 듣게 됩니다." 단어목록이 하나씩 증가하는 각 단어폭 시 작 전에 위와 같은 지시문을 들려준다.

중지

1. 3세트 중 적어도 2 세트 이상 정반응 하였을 때, 다음 단어폭으로 진행한다. 그러나 3 세트 중 2세트 이상 오반응 할 경우 다음 단어폭으로 진행하지 않고 검사를 중단한다.

2. 이때, 다음 단어폭으로 진행하는 정반응의 기준은 각 단어목록의 마지막 단어를 회상한 것으로 하고, 목표범주에서 손바닥을 책상에 치는 것에 대한 반응은 포함하지 않는다. 단, 차후 분석을 위해 오반응에 대한 기록은 하도록 한다.

채점

1. 단어폭(span): 피검자가 2 세트 이상 정반응 한 가장 마지막 단어폭. 예를 들어, 단어폭 3에서 3세트 모두 오반응 하였다면 검사를 중단한다. 이러한 경우, 이 피검자의 단어폭은 2 가 된다. 단, 단어폭 3 에서 3 세트 중 1 세트만 정반응 하였다면 단어폭 3 에서 검사를 중단은 하지만 단어폭에는 부분점수 $(0.5)$ 를 부여하여 이 피검자의 단 어폭은 2.5 가 된다.

2. 총점: 정반응 한 세트별로 1점을 부여하여 총점을 구한다.

3. Tap 수: 목표범주 단어 다음에 손바닥으로 책상을 친 것에 대한 정/오반응의 개수를 세어 기록한다. 
Appendix 3. 의미범주기반 작업기억 중재 단어목록 예시

\section{목표범주 1-6 동물, 7-8 교통기관}

\begin{tabular}{|c|c|c|c|c|c|c|}
\hline \multicolumn{7}{|c|}{ span2 } \\
\hline 1 & $\begin{array}{l}\text { 강 } \\
\text { of } \\
\text { 지 }\end{array}$ & $\begin{array}{l}\text { 기 } \\
\text { 차 }\end{array}$ & $\begin{array}{l}\text { 반 } \\
4 \\
4\end{array}$ & 국 & 대제 & 역 \\
\hline 2 & $\stackrel{\text { 빈 }}{+}$ & 禀 & 趆 & $\begin{array}{l}\text { 지 } \\
\text { 핯 }\end{array}$ & $\begin{array}{l}\text { 录 } \\
\text { ह }\end{array}$ & 곷 \\
\hline 3 & $\begin{array}{l}\text { 벗 } \\
\text { 스 }\end{array}$ & 긴 & $\begin{array}{l}\text { 상 } \\
\text { 章 }\end{array}$ & 삭 & $\begin{array}{l}\text { 동 } \\
\text { 하 }\end{array}$ & 시시 \\
\hline 4 & 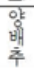 & $\begin{array}{l}\text { 빙 } \\
\text { 액 }\end{array}$ & 삼 & $\begin{array}{l}1 \\
\text { 공 } \\
0 \\
0 \\
0\end{array}$ & $\begin{array}{l}\text { 맘 } \\
\text { 차 }\end{array}$ & 罚 \\
\hline 5 & $\begin{array}{l}\text { 웡 } \\
\text { 이 }\end{array}$ & $\begin{array}{l}\text { 잠 } \\
\text { 적 }\end{array}$ & $\begin{array}{l}\text { 서 } \\
\text { 탁 }\end{array}$ & 贸 & $\begin{array}{l}\text { 잗 } \\
\text { 촟 }\end{array}$ & 홍 \\
\hline 6 & 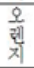 & 댓 & $\begin{array}{l}\text { 여 } \\
\text { 갠ㅅㄴ }\end{array}$ & $\begin{array}{l}\text { 기 } \\
\text { 차 }\end{array}$ & 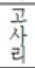 & $\begin{array}{l}\text { 강 } \\
\text { of } \\
\text { 지 }\end{array}$ \\
\hline
\end{tabular}

\begin{tabular}{|c|c|c|c|c|c|c|}
\hline 7 & 가 & $\begin{array}{l}\text { 강 } \\
\text { 아 }\end{array}$ & $\begin{array}{l}\text { 바 } \\
\text { ㄴ }\end{array}$ & 착 & 역 & $\begin{array}{l}\text { 댈 } \\
\text { 지 }\end{array}$ \\
\hline 8 & $\begin{array}{l}\stackrel{\text { 비 }}{\stackrel{4}{ }}\end{array}$ & $\frac{E}{E^{\prime}}$ & $\frac{E}{2}$ & $\begin{array}{l}ㅋ ㅗ \\
\text { 끼 } \\
\text { ㄹ }\end{array}$ & $\begin{array}{l}\text { X] } \\
\text { 항 } \\
\text { 쳘 }\end{array}$ & 胥 \\
\hline 9 & $\begin{array}{l}\text { 길 } \\
\text { 란 }\end{array}$ & $\begin{array}{l}\text { 벗 } \\
\text { 스 }\end{array}$ & 상 & 랙 & $\begin{array}{l}\text { 동 } \\
\text { 마 }\end{array}$ & $\begin{array}{l}\text { 사 } \\
\text { 자 }\end{array}$ \\
\hline 10 & $\begin{array}{l}\text { 양 } \\
\text { 백 } \\
\text { 추 }\end{array}$ & $\begin{array}{l}\text { 삼 } \\
\text { 슴 }\end{array}$ & $\begin{array}{l}\text { 빅 } \\
\text { 행 } \\
\text { 기 }\end{array}$ & 막 & 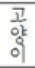 & 㞻 \\
\hline 11 & $\begin{array}{l}\text { 작 } \\
\text { 걱 }\end{array}$ & $\begin{array}{l}\text { 윳 } \\
\text { 잉 }\end{array}$ & $\begin{array}{l}\text { 세 } \\
\text { 픽 } \\
\text { 기 }\end{array}$ & 孯 & 홍이 & $\begin{array}{l}\text { 잠 } \\
\text { 몿 } \\
\end{array}$ \\
\hline 12 & 욜 & $\begin{array}{l}\text { 역 } \\
\text { 갠 } \\
\text { 슨 }\end{array}$ & 재 & $\begin{array}{l}\text { 강 } \\
\text { or } \\
\text { 지 }\end{array}$ & 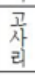 & $\begin{array}{l}\text { 기 } \\
\text { 차 }\end{array}$ \\
\hline
\end{tabular}

\begin{tabular}{|c|c|c|c|c|c|c|c|c|c|c|c|c|}
\hline \multicolumn{13}{|c|}{ span4 } \\
\hline 1 & $\begin{array}{l}\text { 강 } \\
\text { of } \\
\text { x }\end{array}$ & 기차 & 칠 & 오이 & 대재 & 격 & 틀 & 순 & $\begin{array}{l}\text { 疎 } \\
\text { 리 }\end{array}$ & 길 & $\begin{array}{l}\text { 겅 } \\
\text { 올 }\end{array}$ & $\begin{array}{l}\text { 지 } \\
\text { 한 } \\
\text { 쳘 }\end{array}$ \\
\hline 2 & 사 & $\begin{array}{l}\text { 경 } \\
\text { 포도 }\end{array}$ & 벗 & 래새 & 시믗 & 삼 & 긋 & 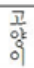 & $\begin{array}{l}\text { 빔 } \\
\text { 행 }\end{array}$ & 웟ㅇㅎㅇ & 맘 & 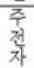 \\
\hline 3 & $\begin{array}{l}\text { 잠 } \\
\text { 奀 }\end{array}$ & 밤 & 홍 & 국 & 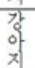 & $\begin{array}{l}\text { 잠 } \\
\text { 稁 }\end{array}$ & 대 지 & 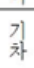 & $\begin{array}{l}\text { 비 } \\
\text { 누 }\end{array}$ & 곷 & 역여선 & 㫐 \\
\hline 4 & $\begin{array}{l}\text { 상 } \\
\text { 章 }\end{array}$ & 콖 & 틀 & $\begin{array}{l}\text { 지 } \\
\text { 핯 }\end{array}$ & 돔 & $\begin{array}{l}\text { 길 } \\
\text { 린 }\end{array}$ & $\begin{array}{l}\text { 삼 } \\
\text { 자 }\end{array}$ & 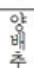 & 벗 & 랫시 & $\begin{array}{l}\text { 삼 } \\
\text { 슴 }\end{array}$ & $\begin{array}{l}\text { 㟧 } \\
\text { 빕 }\end{array}$ \\
\hline 5 & $\begin{array}{l}\text { 빙 } \\
\text { 영 }\end{array}$ & $\begin{array}{l}7 \\
7 \\
01 \\
0\end{array}$ & $\begin{array}{l}\text { 세 } \\
\text { 탁 }\end{array}$ & 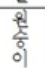 & 卧 & $\begin{array}{l}\text { 마 } \\
\text { 차 }\end{array}$ & 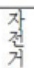 & 레제 & 홍 & 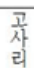 & $\begin{array}{l}\text { 가의 } \\
\text { 이 }\end{array}$ & 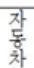 \\
\hline 6 & 삭 & 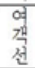 & 패지 & 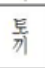 & 긴 & 숙 & 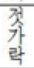 & $\begin{array}{l}\text { 录 } \\
\text { हो }\end{array}$ & $\begin{array}{l}\text { 지 } \\
\text { 할 }\end{array}$ & 比 & $\begin{array}{l}\text { 商 } \\
\text { val }\end{array}$ & 길 \\
\hline
\end{tabular}

\begin{tabular}{|c|c|c|c|c|c|c|c|c|c|c|c|c|}
\hline 7 & 가 & $\begin{array}{l}\text { 강 } \\
\text { 지 }\end{array}$ & 촐 & 到 & 격 & 옹 & 술 & 结 & 틀 & $\begin{array}{l}\text { 지 } \\
\text { 핯 }\end{array}$ & $\begin{array}{l}\text { 콤 } \\
\text { 列 }\end{array}$ & 걸 \\
\hline 8 & $\begin{array}{l}\text { 버 } \\
\text { 스 }\end{array}$ & $\begin{array}{l}\text { 쳥 } \\
\text { 폳 } \\
\text { | }\end{array}$ & 긴 & $\begin{array}{l}\text { 상 } \\
\text { 자 }\end{array}$ & 기츷 & 테세 & 곳 & 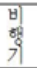 & 상 & 망 & $\begin{array}{l}\text { 고 } \\
0 k \\
0 \mid\end{array}$ & 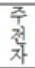 \\
\hline 9 & 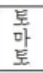 & 웅 & $\begin{array}{l}\text { 자 } \\
\text { 적 }\end{array}$ & $\begin{array}{l}\text { 홍 } \\
\text { हो }\end{array}$ & $\begin{array}{l}\text { 잠 } \\
\text { 홏 }\end{array}$ & $\begin{array}{l}\text { 복 } \\
\text { 홍 }\end{array}$ & $\begin{array}{l}\text { 긱 } \\
\text { 차 }\end{array}$ & 반 & $\begin{array}{l}\text { 강 } \\
\text { of } \\
\text { 자 }\end{array}$ & 댖 & 곡 & 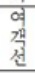 \\
\hline 10 & $\begin{array}{l}\frac{E}{\pi} \\
\text { II }\end{array}$ & 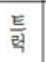 & $\begin{array}{l}\text { 빈 } \\
\text { 年 }\end{array}$ & 곷 & $\begin{array}{l}\text { 콖 } \\
\text { ᄅ己 }\end{array}$ & $\begin{array}{l}\text { 지 } \\
\text { 할 }\end{array}$ & $\begin{array}{l}\text { 벗 } \\
\text { 스 }\end{array}$ & 길 & 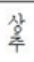 & 동 & 택 시 & 사자 \\
\hline 11 & $\begin{array}{l}\text { 야 } \\
\text { 배 } \\
\text { 추 }\end{array}$ & 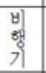 & 삼 & $\begin{array}{l}\text { 마 } \\
\text { 차 }\end{array}$ & 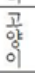 & 嵓 & $\begin{array}{l}\text { 세 } \\
\text { 탁 }\end{array}$ & $\begin{array}{l}\text { 웡 } \\
\text { 옹 }\end{array}$ & 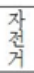 & $\begin{array}{l}\text { 홍 } \\
\text { 이 }\end{array}$ & $\begin{array}{l}\text { 잠 } \\
\text { 新 }\end{array}$ & 漚 \\
\hline 12 & 대지 & 원 & $\begin{array}{l}\text { 역 } \\
\text { 能 }\end{array}$ & 각 & 삭 살 & & 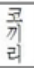 & $\begin{array}{l}\text { 지 } \\
\text { 할 }\end{array}$ & 삭 & 荠 & 숙 & 昙 \\
\hline
\end{tabular}

\begin{tabular}{|c|c|c|c|c|c|c|c|c|c|}
\hline \multicolumn{10}{|c|}{ span3 } \\
\hline 1 & 惖 & 틀 & 삭 & 숙 & 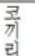 & $\begin{array}{l}\text { 지 } \\
\text { 핯견 }\end{array}$ & 벗 & 저ㄱㅏㅏㄹ & 길 \\
\hline 2 & 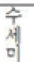 & 탯 & 상 & 삼 & 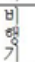 & 밪 & 죽 & $\begin{array}{l}\text { 공 } \\
\text { 잉 }\end{array}$ & 맟 \\
\hline 3 & 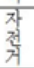 & $\begin{array}{l}\text { 웟 } \\
\text { 잉 }\end{array}$ & $\begin{array}{l}\text { 참 } \\
\text { 9 }\end{array}$ & 홓잉 & 잫 & 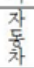 & $\begin{array}{l}\text { 긱 } \\
\text { 차 }\end{array}$ & 치 & $\begin{array}{l}\text { 강 } \\
\text { of } \\
\text { 지 }\end{array}$ \\
\hline 4 & 멸 & $\begin{array}{l}\text { 대 } \\
\text { 지 }\end{array}$ & 역 & 특 & 당 & $\begin{array}{l}\frac{E}{D} \\
\text { 足 }\end{array}$ & $\begin{array}{l}\text { 颡 } \\
\text { 己 }\end{array}$ & 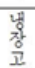 & $\begin{array}{l}\text { 짐 } \\
\text { 할 }\end{array}$ \\
\hline 5 & 벗 & 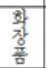 & 길 & $\begin{array}{l}\text { 콩 } \\
4 \\
\text { 물 }\end{array}$ & 사 자 & 탯ㅅ & 삼 & $\begin{array}{l} \\
\text { 병 } \\
\text { ? }\end{array}$ & 실 \\
\hline 6 & $\begin{array}{l}\text { 공 } \\
\text { ok } \\
\text { o| }\end{array}$ & 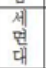 & 맞 & $\begin{array}{l}\text { 졀 } \\
\text { 걱 }\end{array}$ & $\begin{array}{l}\text { 야 } \\
\text { 하 }\end{array}$ & 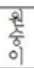 & $\begin{array}{l}\text { 可 } \\
\text { च }\end{array}$ & $\begin{array}{l}\text { 홍 } \\
\text { 이 }\end{array}$ & $\begin{array}{l}\text { 잠 } \\
\text { 차 }\end{array}$ \\
\hline
\end{tabular}

\begin{tabular}{|c|c|c|c|c|c|c|c|c|c|}
\hline 7 & 틀 & 㫐 & $\begin{array}{l}\text { 삭 } \\
\text { ㄱ }\end{array}$ & 숙 & 항 & $\begin{array}{l}\text { 콤 } \\
\text { ᄅ| }\end{array}$ & 길 & 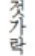 & 벗 \\
\hline 8 & $\begin{array}{l}\text { 菕 } \\
\text { vol }\end{array}$ & $\begin{array}{l}\text { 상 } \\
\text { 자 }\end{array}$ & 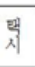 & $\begin{array}{l}\text { 비 } \\
\text { 핵 } \\
\text { 기 }\end{array}$ & 삼 & $\begin{array}{l}\text { 밤 } \\
\text { 갖 }\end{array}$ & 죽 & 학 & $\begin{array}{l}\text { 고 } \\
\text { 야 } \\
\text { ᄋ }\end{array}$ \\
\hline 9 & 웟 & $\begin{array}{l}\text { 작 } \\
\text { 적 }\end{array}$ & 참 & $\begin{array}{l}\text { 잗 } \\
\text { 차 }\end{array}$ & $\begin{array}{l}\text { 잠 } \\
\stackrel{+}{+}\end{array}$ & $\begin{array}{l}\text { 辛 } \\
\text { के }\end{array}$ & $\begin{array}{l}7 \text { 강 } \\
\text { 아 } \\
x\end{array}$ & 치 & $\begin{array}{l}\text { 기 } \\
\text { 차 }\end{array}$ \\
\hline 10 & ( & 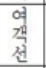 & $\begin{array}{l}\text { 멷 } \\
\frac{1}{7}\end{array}$ & $\begin{array}{l}\text { E⿱ } \\
\text { गो }\end{array}$ & 항 & 특 & $\begin{array}{l}\text { 지 } \\
\text { 할 }\end{array}$ & 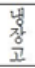 & $\begin{array}{l}\text { 코 } \\
\text { ग } \\
\text { 리 }\end{array}$ \\
\hline 11 & 길 & $\begin{array}{l}\text { 화잠 } \\
\text { 害 }\end{array}$ & 벗 & $\begin{array}{l}\text { 妻 } \\
\text { 둘 }\end{array}$ & 패새 & $\begin{array}{l}\text { 사자 } \\
\text { 강 }\end{array}$ & $\begin{array}{l}\text { 빔 } \\
\text { 이 }\end{array}$ & 슴 & $\begin{array}{l}\text { 싱 } \\
\text { 대당 }\end{array}$ \\
\hline 12 & 막 & $\begin{array}{l}\text { 세 } \\
\text { 멸 } \\
\text { 대 }\end{array}$ & & $\begin{array}{l}\text { ok } \\
\text { aे }\end{array}$ & 월 & $\begin{array}{l}\text { 전 } \\
\text { 걱 }\end{array}$ & 䇏 & 차 & 말 \\
\hline
\end{tabular}

\begin{tabular}{|c|c|c|c|c|c|c|c|c|c|c|c|c|c|c|c|}
\hline 7 & 벗 & 길 & 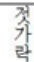 & $\begin{array}{l}\text { 숫 } \\
\text { 미 }\end{array}$ & 긱 & $\begin{array}{l}72 \\
\text { of } \\
x \\
x\end{array}$ & \begin{tabular}{|l} 
삼 \\
슴
\end{tabular} & \begin{tabular}{|l|} 
밤 \\
x
\end{tabular} & $\begin{array}{l}\text { 밤 } \\
\text { 행 }\end{array}$ & 暍 & 죽 & 惖 & 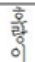 & 작걱 & 찰 \\
\hline 8 & $\begin{array}{l}\text { 잘 } \\
\text {. }\end{array}$ & 랫ㅅㅅ & 샂 & 역 & 대지 & 亮 & \begin{tabular}{|l} 
면 \\
독
\end{tabular} & 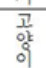 & 맟 & $\begin{array}{l}\text { 콕 } \\
\text { 吾 }\end{array}$ & $\begin{array}{l}\text { 지 } \\
\text { 할 }\end{array}$ & 단 & 자마맟 & $\begin{array}{l}\frac{1}{8} \\
\frac{10}{3}\end{array}$ & $\begin{array}{l}\text { 강 } \\
\text { 아 }\end{array}$ \\
\hline 9 & 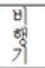 & 삼 & 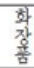 & $\begin{array}{l}\text { 疍 } \\
\text { 물 }\end{array}$ & $\begin{array}{l}\text { E⿱ } \\
\text { DI }\end{array}$ & 틀 & $\begin{array}{l}\text { 웟 } \\
\text { 윙 }\end{array}$ & $\begin{array}{l}\text { 잠 } \\
\text { 적 }\end{array}$ & $\begin{array}{l}\text { 싱 } \\
\text { 금 }\end{array}$ & 벗 & $\begin{array}{l}\text { 세 } \\
\text { 면 } \\
\text { 대 }\end{array}$ & $\begin{array}{l}\text { 길 } \\
\text { 린 }\end{array}$ & 대지 & $\begin{array}{l}\text { 얓 } \\
\text { 파 }\end{array}$ & $\begin{array}{l}\text { 기 } \\
\text { 차 }\end{array}$ \\
\hline 10 & $\begin{array}{l}\text { 만 } \\
\text { 리 }\end{array}$ & $\begin{array}{l}\text { 공․ } \\
\text { ok } \\
\text { o }\end{array}$ & 마 & 작 & $\begin{array}{l}\text { 코 } \\
\text { गो } \\
\text { ये }\end{array}$ & 출 & $\begin{array}{l}9 \\
01\end{array}$ & $\begin{array}{l}\text { 잠 } \\
\text { ㅊㅊㅊ }\end{array}$ & $\begin{array}{l}\text { 홍 } \\
\text { 잉 }\end{array}$ & $\begin{array}{l}\text { 사 } \\
\text { 자 }\end{array}$ & 수권 & 탯 & 여ㄱㅕㅕㄱ & $\begin{array}{l}\text { 겅 } \\
\text { s. }\end{array}$ & 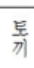 \\
\hline 11 & 옹 & 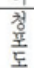 & $\begin{array}{l}\text { 작 } \\
\text { 걱 }\end{array}$ & 시믗 & $\begin{array}{l}\text { 버 } \\
\text { 스 }\end{array}$ & $\begin{array}{l}\text { 길 } \\
\text { 란 }\end{array}$ & 기 & $\begin{array}{l}\text { 강 } \\
\text { of } \\
\text {. }\end{array}$ & 곳 & $\begin{array}{l}\text { 중 } \\
\text { 施 }\end{array}$ & $\begin{array}{l}\text { 삿 } \\
\text { 슴 }\end{array}$ & $\begin{array}{l}\text { 빙 } \\
\text { 핵 }\end{array}$ & 㾦 & 탁 & $\begin{array}{l}\text { 통 } \\
\text { 맡 }\end{array}$ \\
\hline 12 & $\begin{array}{l}\text { 흐숭 } \\
\text { 아 }\end{array}$ & $\begin{array}{l}\text { 자담ㅇ․ } \\
\text { 차 }\end{array}$ & $\begin{array}{l}\text { 홀 } \\
\text { 이의 }\end{array}$ & 사자 & $\begin{array}{l}\text { 반 } \\
\text { ㄴ }\end{array}$ & 래새 & 역 & 착 & 댖 & $\begin{array}{l}7 \\
7 \\
0 \\
0 \\
0\end{array}$ & 맟 & $\begin{array}{l}\text { 빈 } \\
\stackrel{+}{*}\end{array}$ & 곷 & 길 & $\begin{array}{l}\text { 질 } \\
\text { 할 }\end{array}$ \\
\hline
\end{tabular}




\title{
국문초록
}

\author{
의미범주기반 작업기억 중재가 실어증환자의 문장이해 및 단어유창성에 미치는 일반화 효과 \\ 손희정 · 성지은 \\ 이화여자대학교 대학원 언어병리학과
}

배경 및 목적: 본 연구는 실어증환자를 대상으로 의미범주기반 작업기억 중재를 실시하여 작업기억과 문장이해 및 단어유창성으로의 일반화 효과를 알아보고자 하였다. 실어증환자는 뇌손상으로 인해 인지 및 언어장애가 나타나며, 작업기억은 언어 및 인지 관련 과제를 처리하는 데 있어 정보를 유지하는 동시에 정보의 조작 및 수행에 관여하는 근본적인 기제로 연구되어 왔다. 이에 본 연구는 이러한 작 업기억이론에 근거하여 의미범주기반 작업기억 중재를 개발하여 그 효과를 검증하고자 한다. 방법: 실어증환자 7명을 대상으로 6-8주 에 걸쳐서 주 2-3회 중재를 실시하였고, 사전·사후 평가를 포함하여 총 16 회기 동안 진행되었다. 의미범주기반 작업기억 중재는 특정 작 업기억 과제를 반복하는 동안 순차적으로 단서가 제공되는 중재 프로토콜이다. 결과: 중재 작업기억 과제의 단어폭이 통계적으로 유의 한 증가를 보였고, 비중재 작업기억 과제에서는 단어 바로 따라말하기 과제에서만 유의한 증가를 보였다. 문장이해과제 정확도와 단어 유창성 과제 중 동물 범주유창성 과제에서 유의미한 증가를 보였다. 논의 및 결론: 의미범주기반 작업기억 중재가 비중재 작업기억 과 제와 음소유창성 과제로의 일반화 효과는 제한적이었으나 중재 작업기억 과제와 문장이해, 범주유창성 과제로의 중재 및 일반화 효과 를 나타냈다. 의미범주기반 작업기억 중재는 실어증의 근본적인 기제와 관련된 인지과정인 작업기억을 촉진하여 언어능력으로 확장하 는 중재기법으로 다양한 유형의 실어증환자를 대상으로 작업기억뿐 아니라 언어능력의 향상을 가져올 수 있다는 점에서 의미가 있다.

핵심어: 작업기억, 중재, 의미범주, 문장이해, 단어유창성, 실어증

본 연구는 2014년도 정부재원으로 한국연구재단의 지원에 의한 연구임(No. NRF-2014S1A5A8018080).

\section{참고문헌}

강연욱, 진주희, 나덕렬, 이정희, 박재설(2000). 통제단어연상검사(Controlled Oral Word Association Test)의 노인규준연구. 한국심리학회지: 임상, $19,385-392$.

고은(2004). 사물-색상 짝짓기 과제 수행에서 나타난 실어증환자의 시각적 의미기억. 언어치료연구, 13, 1-14.

김애리, 심현섭, 김영태(2004). 유창성실어증과 비유창성실어증환자의 생성이름대기 특성. 음성과학, 11, 151-161.

김유빈, 성지은, 김연희(2013). 구어 및 비구어 작업기억 용량과 실어증환자의 문장이해능력 간의 상관. 언어치료연구, 22, 1-16.

김정숙, 강수균(2005). 상위범주화 훈련이 알츠하이머형 치매환자의 이름대기에 미치는 효과. 난청과 언어장애, 28, 93-114.

김향희, 나덕렬(2001). 파라다이스-한국판-웨스턴실어증검사. 서울:파라다이스 복지재단.

박태진, 박선희, 김태호(2006). 한국어 어휘특성들이 기억폭에 미치는 효과. 인지과학, 17, 15-27.

서희영, 김초복(2014). 영역특수성에 따른 작업기억 훈련의 효과-메타분석. 한국심리학회지: 인지 및 생물, 26, 207-231.

성지은(2010). 실어증환자의 단기기억 및 작업기억 용량과 실어증 중증도 및 문장 처리와의 상관. 언어청각장애연구, 15, 285-297.

성지은(2011). 말언어장애군의 단기기억 및 작업기억용량 측정을 위한 지시하기과제 개발 예비 연구: 재검사 신뢰도 및 타당도. 언어청각장애연구, 16,

185-201.

성지은(2015). 한국어 어순 규범성과 문장유형이 노년층 문장이해능력에 미치는 영향 및 작업기억용량과의 관계. 언어청각장애연구, 20,24-33.

신현정(2003). 인터넷을 이용하여 작성된 범주규준의 타당도 연구 I. 한국심리학회지: 실험, 15, 303-347.

안길만(2010). 작업기억 강화프로그램이 알츠하이머형 치매환자의 단어유창성과 문장이해력에 미치는 효과. 대구대학교대학원 석사학위논문. 엄보라(2015). 문장 따라말하기를 활용한 작업기억 중재가 실어증환자의 문장이해능력에 미치는 효과. 이화여자대학교대학원 석사학위논문. 이관용(1991). 우리말 범주규준조사: 본보기산출빈도, 전형성, 그리고 세부특징조사. 한국심리학회지: 실험 및 인지, 3, 131-160. 
이옥분(2003). 협력학습을 통한 인지적 언어중재가 실어증자들의 언어능력과 의사소통 기능에 미치는 영향. 대구대학교대학원 박사학위논문.

이진숙(1992). 읽기장애아에 있어서 음운중심 및 의미중심 범주화 자극제시 조건이 단어회상에 미치는 효과에 관한 일 연구. 이화여자대학교대학원 석사학위논문.

조수진, 김수정(2002). 실어증환자의 능·피동문 이해와작업기억의 상관관계. 한국언어청각학회 학술대회 발표논문 모음집, 62-69.

최현미, 성지은(2014). 실어증환자의 생성이름대기 능력과작업기억용량과의 관계. 언어치료연구, 23, 23-34.

현정민, 성지은, 정지향, 강희진, 김희진(2013). 경도인지장애 환자의 통사적 복잡성에 따른 격조사처리능력. 언어청각장애연구, 18, 35-46.

David Wechsler (2008). 한국판 웩스러 성인용 지능 검사4판(황순택, 김지혜, 박광배, 최진영, 홍상황 역). 대구: 한국심리주식회사. 